\title{
Genetic Variation and Adaptation in Africa: Implications for Human Evolution and Disease
}

\author{
Felicia Gomez $^{1,2,3,4}$, Jibril Hirbo ${ }^{1,3,5}$, and Sarah A. Tishkoff ${ }^{1}$ \\ ${ }^{1}$ Department of Genetics and Biology, School of Medicine and School of Arts and Sciences, University \\ of Pennsylvania, Philadelphia, Pennsylvania 19104 \\ ${ }^{2}$ Hominid Paleobiology Doctoral Program and The Center for the Advanced Study of Hominid Paleobiology, \\ Department of Anthropology, The George Washington University, Washington, D.C. 20052 \\ Correspondence: tishkoff@mail.med.upenn.edu
}

\begin{abstract}
Because modern humans originated in Africa and have adapted to diverse environments, African populations have high levels of genetic and phenotypic diversity. Thus, genomic studies of diverse African ethnic groups are essential for understanding human evolutionary history and how this leads to differential disease risk in all humans. Comparative studies of genetic diversity within and between African ethnic groups creates an opportunity to reconstruct some of the earliest events in human population history and are useful for identifying patterns of genetic variation that have been influenced by recent natural selection. Here we describe what is currently known about genetic variation and evolutionary history of diverse African ethnic groups. We also describe examples of recent natural selection in African genomes and how these data are informative for understanding the frequency of many genetic traits, including those that cause disease susceptibility in African populations and populations of recent African descent.
\end{abstract}

\begin{abstract}
A frica is where modern humans evolved and Ais the starting place for the global expansion of our species (Stringer and Andrews 1988; Stringer 1994; Templeton 2002). African populations also have the highest levels of genetic and phenotypic variation among all humans. This variation is informative for characterizing demographic history in Africa, including times when populations increased in size, contracted,
\end{abstract}

migrated, or when admixture between them occurred. Genetic variation also provides data that are useful in identifying local adaptation to diverse environments (Campbell and Tishkoff 2008). Characterizing human genetic variation and examining phenotypic variation in extant African populations is fundamental to the identification of genes that play a role in function, adaptation, and complex disease susceptibility

\footnotetext{
${ }^{3}$ These authors contributed equally to this work.

${ }^{4}$ Current address: Division of Statistical Genetics, Department of Genetics, Washington University School of Medicine in St. Louis, St. Louis, Missouri 63108.

${ }^{5}$ Current address: Department of Biological Sciences, Vanderbilt University, 7280 BSB/MRB III, VU Station B, Box 35-1634, Nashville, Tennessee 37235-1634.

Editor: Aravinda Chakravarti

Additional Perspectives on Human Variation available at www.cshperspectives.org

Copyright (C) 2014 Cold Spring Harbor Laboratory Press; all rights reserved; doi: 10.1101/cshperspect.a008524

Cite this article as Cold Spring Harb Perspect Biol 2014;6:a008524
} 
F. Gomez et al.

in Africans and populations of recent African descent.

\section{LINGUISTIC, CULTURAL, AND SUBSISTENCE DIVERSITY IN AFRICA}

There are over 2000 indigenous languages spoken in Africa. They are classified into four major linguistic families-Niger-Kordofanian (spoken primarily by agriculturalist populations located in large contiguous regions of sub-Saharan Africa from West Africa to eastern and southern Africa), Nilo-Saharan (spoken predominantly by pastoralist populations in central and eastern Africa), Afroasiatic (spoken predominantly by agro-pastoralists and pastoralist populations in northern and eastern Africa), and Khoesan (a language family that contains click consonants, spoken by hunter-gatherer San populations in southern Africa as well as the Hadza and Sandawe hunter-gatherers in Tanzania) (Fig. 1).

African populations also live in a diverse range of environments (including deserts, savannahs, and tropical environments), have different exposures to infectious disease, and have diverse diets and subsistence patterns. Because African populations exist in such a broad spectrum of environments, they may have regional or population-specific genetic variants that play a role in local adaptation to different selection pressures. The study of African genomic variation is uniquely interesting because of the large proportion of human genetic variation observed in African populations and the length of human history in the continent.

\section{PATTERNS OF GENETIC DIVERSITY AND DEMOGRAPHIC HISTORY IN AFRICA}

The characterization of human genetic variation began with studies that described human blood groups and protein polymorphisms (Cavalli-Sforza 1994). Since then, it has grown to include numerous studies of mtDNA (mitochondrial DNA) that is inherited maternally, Y chromosome variation that is inherited paternally, and loci from the full nuclear genome that include sequences of repetitive DNA, single nucleotide polymorphisms (SNPs), and struc- tural variation (SVs) (Campbell and Tishkoff 2008).

The pattern of genetic variation at these loci in modern African populations reflects their demographic and evolutionary histories (Campbell and Tishkoff 2008). Modern humans evolved in Africa $\sim 200$ kya (thousand years ago) and migrated from Africa within the past 50-100 kya, successfully colonizing most of the terrestrial parts of the globe (Campbell and Tishkoff 2008). This is called the "Out-of-Africa" migration. Currently, the precise location of the origin of modern humans remains a contentious issue. Some argue that South Africa is the location where our species originated (Tishkoff et al. 2009; Compton 2011; Henn et al. 2011), whereas others argue that East Africa is where modern humans originated (Prugnolle et al. 2005; Ray et al. 2005). However, these inferences are biased by the lack of archeological and fossil data in tropical areas of Africa and the fact that the geographic location of populations in the present may have differed in the past.

Genetic evidence also indicates that human populations underwent several major population expansions at different time periods over the last 100 ky (Rogers and Harpending 1992; Harpending et al. 1993; Excoffier and Schneider 1999; Atkinson et al. 2009; Cox et al. 2009): an initial major population expansion in Africa 110-70 kya (Rogers and Harpending 1992; Harpending et al. 1993; Excoffier and Schneider 1999; Atkinson et al. 2008, 2009) and subsequent migration and expansion events around the globe at $\sim 60-55$ kya (Atkinson et al. 2009), $\sim 40-25 \mathrm{kya}$, and $\sim 12$ kya (Harpending et al. 1993; Atkinson et al. 2009; Cox et al. 2009).

Prior to the domestication of plants and animals $\sim 10,000$ years ago, all human populations practiced hunting-gathering/foraging for subsistence. Although we do not know their original homeland, ancestors of the extant African hunter-gatherer populations, including the current Khoesan speakers, migrated into central, eastern, and southern Africa probably $>20$ kya (Nurse 1997; Ehret 2002). It is speculated that speakers of Khoesan languages were widespread throughout a contiguous area that encompassed southern and eastern African re- 


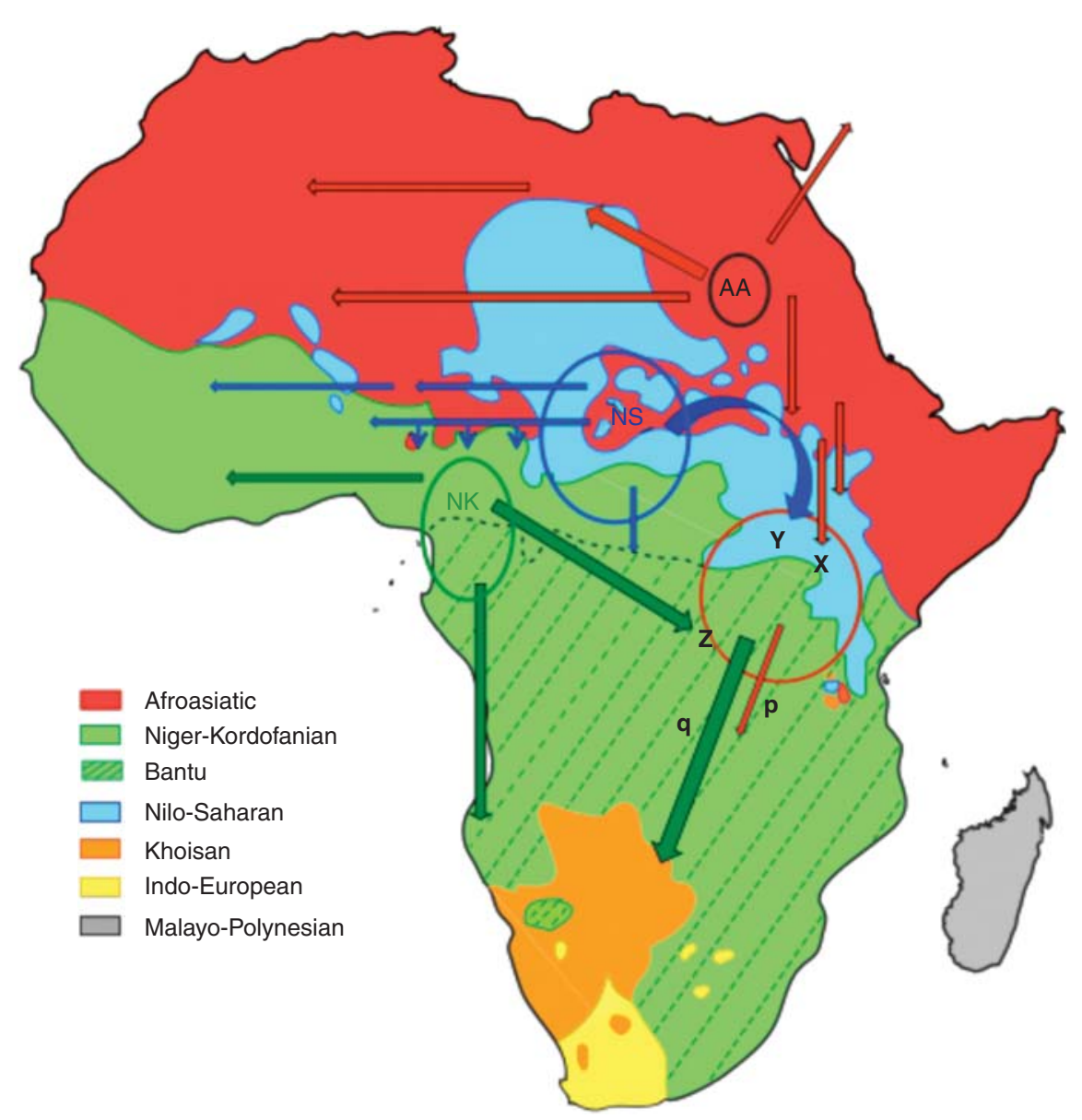

Figure 1. The geographic distribution of the major linguistic groups in Africa. The map was drawn using information (geographic locations of ethnic speakers in Africa that are based on published sources) from Haspelmath et al. (2008) (wals.info/), www.ethnologue.com (International HapMap 2005), Greenberg (1963, 1972), Vansina (1995), and Ehret (1971, 1993, 1995, 2001b). Geographic range occupied by Bantu speakers, the major linguistic subfamily within the Niger-Kordofanian phylum mentioned in the text, is also shown. Putative centers of origin and estimated time of initial expansion based on linguistic studies for three of the four language families are also listed: AA, Afroasiatic (14 kya) (Ehret 1995); NS, Nilo-Saharan (Blench 1993; Ehret 1993; Blench 2006); NK, Niger-Kordofanian (5 kya) (Nurse 1997; Ehret 2001a). Afroasiatic-speaking pastoralists were the first food-producing populations to migrate into East Africa circa 5 kya (X) (Leakey 1931; Butzer 1969; Robbins 1972; Barthelme 1977); followed by Nilo-Saharan-speaking pastoralists circa 3 kya (Y) (Leakey 1931; Bower 1973; Ambrose 1982; Distefano 1990), and later Bantu-speaking agriculturalists after circa 2.5 kya (Z) (Posnansky 1961a,b). P and q represent initial expansion of pastoralists (2.5 kya) and later Bantuspeaking agriculturalists (after 2 kya) to southern Africa from East Africa, respectively.

gions (Sutton 1973; Smith 1992). Based on archaeological and linguistic data, it is hypothesized that recent migration events that occurred, due to changes in subsistence patterns, modified the genetic landscape in Africa through admixture of populations practicing pastoralism and/ or agriculture with indigenous hunter-gatherer populations. For example, the expansion of agriculturalists from Central-West Africa and the migration of pastoralist populations from northeastern Africa have contributed to the current genetic landscape in Africa. One of the larg- 
F. Gomez et al.

est migration events in Africa that was mediated by a shift in subsistence patterns was the migration of Bantu-speaking populations, a subfamily of Niger-Kordofanian languages, from their proposed homeland in Nigeria/Cameroon across sub-Saharan Africa within the past 5000 years (Fig. 1) (Nurse 1997; Ehret 2001a). The result of this expansion is the current predominance of Bantu languages in many African countries. Other major migration events have included the migration of Nilo-Saharan pastoralists from their homeland in Chad/Sudan, both westward across the Sahel $\sim 7000$ years ago and eastward into Kenya and Tanzania within the past $\sim 3000$ years (Blench 1993; Ehret 1993). Afro-Asiatic-speaking agro-pastoralists migrated from their homeland, which encompassed the Nile Valley to the Ethiopian highlands, into western, northern, and eastern Africa within the past 8000-5000 years (Ehret 1995, 1998) (Fig. 1). Demographic history in Africa has also been influenced by the more recent migration of nonAfricans into Africa. Most noteworthy is the migration of southwestern Asians into Northern and Eastern Africa within the past 3000 years (Van Beek 1967; Butzer 1981; Phillipson 2009). Europeans, southern and eastern Asians have also migrated into Southern Africa within the past several hundred years.

Consistent with the "Out of Africa" model of modern human origins, analyses of genetic data indicate that Africans have higher levels of genetic diversity than non-Africans (Cann et al. 1987, 2002; Tishkoff et al. 1998; Marth et al. 2004). Overall, the extant patterns of genetic variation in global populations suggests serial founder events, with increasing genetic distance correlated with geographic distance from East Africa, indicating the cumulative effect of genetic drift as humans expanded into the rest of the world (Prugnolle et al. 2005; Ramachandran et al. 2005; Hofer et al. 2009). Studies of autosomal genetic variation show that genetic distance between populations also increases with geographic distance within Africa (Prugnolle et al. 2005; Ramachandran et al. 2005; Hofer et al. 2009; Tishkoff et al. 2009). The greater genetic diversity in sub-Saharan Africans, as compared to other continental populations, may also be partially a result of ancient admixture with yetto-be identified archaic population(s) (Zietkiewicz et al. 1998; Labuda et al. 2000; Plagnol and Wall 2006; Hammer et al. 2011; Lachance et al. 2012), analogous to the proposed admixture between Neanderthals and modern humans in Eurasia (Reich et al. 2010, 2011; Abi-Rached et al. 2011; Green et al. 2011; Yotova et al. 2011). Genomic introgression from Neanderthals has been detected in some East African populations but was inferred to be a signature of recent backmigrations from Eurasia (Wang et al. 2013).

Many of the recent population genetic studies of African populations are based on analysis of genetic markers that were genotyped in a small number of populations that are part of the CEPH-HGDP collection (Centre d'Étude du Polymorphisme Humain-Human Genome Diversity Panel) or the International Haplotype Map (HapMap) Project (Batzer and Deininger 2002; Rosenberg et al. 2002; Li et al. 2008). Only six African populations are included in the CEPH-HGDP panel, whereas the International HapMap Project includes just three African populations (Niger-Kordofanian-speaking Yoruba from Nigeria, Bantu-speaking Luhya from Kenya, and Nilo-Saharan-speaking Maasai from Kenya). A more recent international collaborative effort that aims to catalogue human genetic variation through whole genome resequencing, the "The 1000 Genomes Project" (2010), originally had only two African populations represented in the project but has since expanded to include the Esan from Nigeria, individuals from The Gambia, the Luhya from Kenya, and the Mende from Sierra Leone. However, it should be noted that all of these populations speak Niger-Kordofanian languages and share recent genetic ancestry. The 1000 Genomes project has also expanded to include people of recent African descent including African Americans from the southwestern United States and African Caribbean individuals from Barbados. Although these projects are important in their description of overall human genetic diversity, they are limited in their coverage of African populations, despite the recent additions (Consortium 2010). Because these projects have sampled a small number of African populations it is likely 
that a substantial portion of human genetic variation will be missed. Thus, it is important to continue to add African populations that are underrepresented in human genomic studies, particularly those speaking languages belonging to the other three language families in Africa. Analysis of genomic variation across a broad range of African populations will be useful for elucidating fine-scale population structure and demographic patterns in African populations.

The current studies of global human genetic variation suggest that human populations may have been divided into distinct subpopulations in Africa prior to the migration of modern humans Out-of-Africa $\sim 100$ kya (Labuda et al. 2000; Satta and Takahata 2004; Adeyemo et al. 2005; Plagnol and Wall 2006; Bryc et al. 2009; Tishkoff et al. 2009; Wall et al. 2009; de Wit 2010; Patterson 2010; Sikora 2010; Henn et al. 2012; Pagani et al. 2012; Schlebusch et al. 2012). For example, we (Tishkoff et al. 2009) identified 14 ancestral population clusters in Africa with four predominant clusters that broadly represent populations from major African geographical regions and those that speak the four African language families mentioned above. The remaining 10 are mainly restricted to specific geographic regions, languages, or in some cases, individual populations (e.g., Hadza huntergatherers). Other studies of African genetic diversity (Adeyemo et al. 2005; Bryc et al. 2009; de Wit 2010; Patterson 2010; Sikora 2010; Henn et al. 2012; Pagani et al. 2012; Schlebusch et al. 2012) have largely recapitulated the regional clusters (Tishkoff et al. 2009) while also adding some fine-scale genetic structure between populations from different ethnicities or populations that speak different languages within the regions studied.

Studies of genetic variation in Africa suggest that even though high levels of mixed ancestry are observed in most African populations, the genetic variation observed in Africa is broadly correlated with geography, language classification (Adeyemo et al. 2005; Bryc et al. 2009; Tishkoff et al. 2009) and subsistence classifications (Tishkoff et al. 2009). For example, genetic variation among Nilo-Saharan and Afroasiaticspeaking populations from both Central and
East Africa (Tishkoff et al. 2009; Bryc et al. 2009) reflect the geographic region from which they originated, and generally shows a complex pattern of admixture between these populations and the Niger-Kordofanian speakers who migrated into the region more recently. Consistent with linguistic evidence regarding the origin of Nilo-Saharan languages in the Chad/Sudan border, the highest proportion of Nilo-Saharan ancestry is observed among southern Sudanese populations (Tishkoff et al. 2009). Additionally, North/Northwest African populations are genetically differentiated from sub-Saharan African populations, but have considerable shared ancestry with East African Afroasiatic speakers (Tishkoff et al. 2009; Henn et al. 2012) and southwest Asian populations (Rosenberg et al. 2002; Behar et al. 2008, 2010; Li et al. 2008; Kopelman et al. 2009; Tishkoff et al. 2009; Atzmon et al. 2010; Bray 2010; Hunter-Zinck 2010; Henn et al. 2012), likely reflecting historic migrations from those source populations into northern Africa. Finally, several studies of genetic variation in the "colored" population from South Africa (Tishkoff et al. 2009; de Wit et al. 2010; Patterson et al. 2010) are consistent with the documented history of this population, which indicates that they have South African Khoesan, Niger-Kordofanian, European, South Asian, and Indonesian ancestors (Tishkoff et al. 2009; de Wit et al. 2010; Patterson et al. 2010).

\section{mEDA AND Y CHROMOSOME VARIATION}

A refined view of uniparental genetic diversity in Africa has been hampered by a lack of extensive sampling in Africa and a lack of consensus on the proper method to estimate mutation rates that are essential to make inferences about human demography. The time to the most recent common ancestor (TMRCA) for mtDNA lineages, based on large datasets, ranges from 121.5 to $221.5 \mathrm{kya}$, (Ingman et al. 2000; Behar et al. 2008), which is older than most estimates of the $\mathrm{Y}$ chromosome TMRCA, which are based on patchy sampling within Africa (60-140 kya) (Thomason 1988; Cruciani et al. 2011; Wei et al. 2013). The fact that there has been limited sampling in Africa is further exemplified by recent 
F. Gomez et al.

results that include more African samples and infer that the TMRCA of the human Y chromosome is similar (120-200 kya) (Mendez et al. 2013) or even older (237-581 kya) than the TMRCA of mtDNA (Ingman et al. 2000; Behar et al. 2008; Francalacci et al. 2013; Mendez et al. 2013; Poznik et al. 2013). Generally, there is a lack of precision in TMRCA estimates reported by different studies using the same marker systems (Francalacci et al. 2013; Mendez et al. 2013; Poznik et al. 2013). Nonetheless, the consensus based on numerous studies, is that human populations exhibit structure (e.g., genetic differences among populations from different regions) based on both mtDNA and Y chromosome variation (Wallace et al. 1999; Ingman et al. 2000; Maca-Meyer et al. 2001; Herrnstadt et al. 2002; Mishmar et al. 2003).

The distribution pattern of uniparental lineages in Africa suggests ancient geographical and cultural subdivision in African. African populations exhibit greater diversity in the $\mathrm{Y}$ chromosome than those of other continents (Hammer 2002). Based on the latest classification of Y chromosome haplogroups (Karafet et al. 2008), A, B, E, and J haplogroups are found in Africans, whereas C, D, and the lineages descending from haplogroup $\mathrm{F}$ are almost exclusively observed outside of sub-Saharan Africa (Fig. 2). The oldest lineages, A and B, with a TMRCA over $\sim 75 \mathrm{kya}$, are present only in Africans. The younger lineages, E and J haplogroups, with a TMRCA less than $75 \mathrm{kya}$, are present in both African and non-African populations (Fig. 2) (Seielstad et al. 1998; Scozzari et al. 1999). Haplogroup E represents the great majority of Y chromosome haplotypes across Africa (Cruciani et al. 2002). Furthermore, the sublineages within these haplogroups exhibit unique regional distribution patterns within Africa (Cruciani 2002, 2010, 2011; Hammer 2002; Luis et al. 2004; Wood et al. 2005; Batini 2007, 2011; Berniell-Lee et al. 2009), with some restricted to specific geographical regions and/or language families (Fig. 3), consistent with substructuring of diverse African populations.

Analogous to variation observed on the Y chromosome, mtDNA haplotypes also show geographic structuring. African populations are characterized by having the oldest haplogroup lineages (L0-L5), with TMRCA over $\sim 80$ kya (Bandelt et al. 1995, 2001; Chen et al. 1995, 2000; Graven et al. 1995; Soodyall et al. 1996; Watson et al. 1996, 1997; Alves-Silva et al. 2000; Torroni et al. 2001; Salas et al. 2002), as well as the M1 haplogroup, an L3 sublineage. Although lineages $\mathrm{M}, \mathrm{N}$, and all of their descending lineages with inferred TMRCA less than 80 kya are found in most global populations, they are observed almost exclusively outside of sub-Saharan Africa. There is also a unique distribution pattern of mtDNA haplotypes across Africa with some lineages restricted to specific geographical regions and/or language families (Fig. 3) (Newman 1980; Vigilant 1990, 1991; Chen et al. 1995, 2000; Ehret 1995, 2006; Watson et al. 1996, 1997; Rando et al. 1998; Krings et al. 1999; Richards et al. 2000; Pereira et al. 2001; Salas et al. 2002; Thomas et al. 2002; Destro-Bisol et al. 2004; Kivisild et al. 2004; Beleza et al. 2005; Coia et al. 2005; Jackson et al. 2005; Cerny et al. 2006, 2008, 2009; Gonzalez et al. 2006; Batini et al. 2007; Gonder et al. 2007; Behar et al. 2008; Coudray et al. 2008; Quintana-Murci et al. 2008, 2010; Castri et al. 2009; Coelho et al. 2009; Poloni et al. 2009; Saunier et al. 2009; Stefflova et al. 2009; Veeramah et al. 2010). Additionally, there is also a predominance of some $\mathrm{Y}$ chromosome and mtDNA lineages in specific regions of Africa. There is also sharing of many of these lineages between regions (Watson et al. 1996, 1997; Pereira et al. 2001; Salas et al. 2002; Beleza et al. 2005; Behar et al. 2008; Quintana-Murci et al. 2008), suggesting that there have been both recent and ancient migration events between these regions over the last 20 ky (Ehret 1967).

Despite the large amount of ethnic and genetic diversity observed in African relative to non-African populations, there has been limited sampling in Africa. Additional sampling and characterization of genetic diversity, particularly from underrepresented central, southern and eastern African countries will be crucial to deciphering fine-scale genetic history of genetically, culturally, and linguistically diverse African populations and for reconstructing both ancient and recent human evolutionary history. 

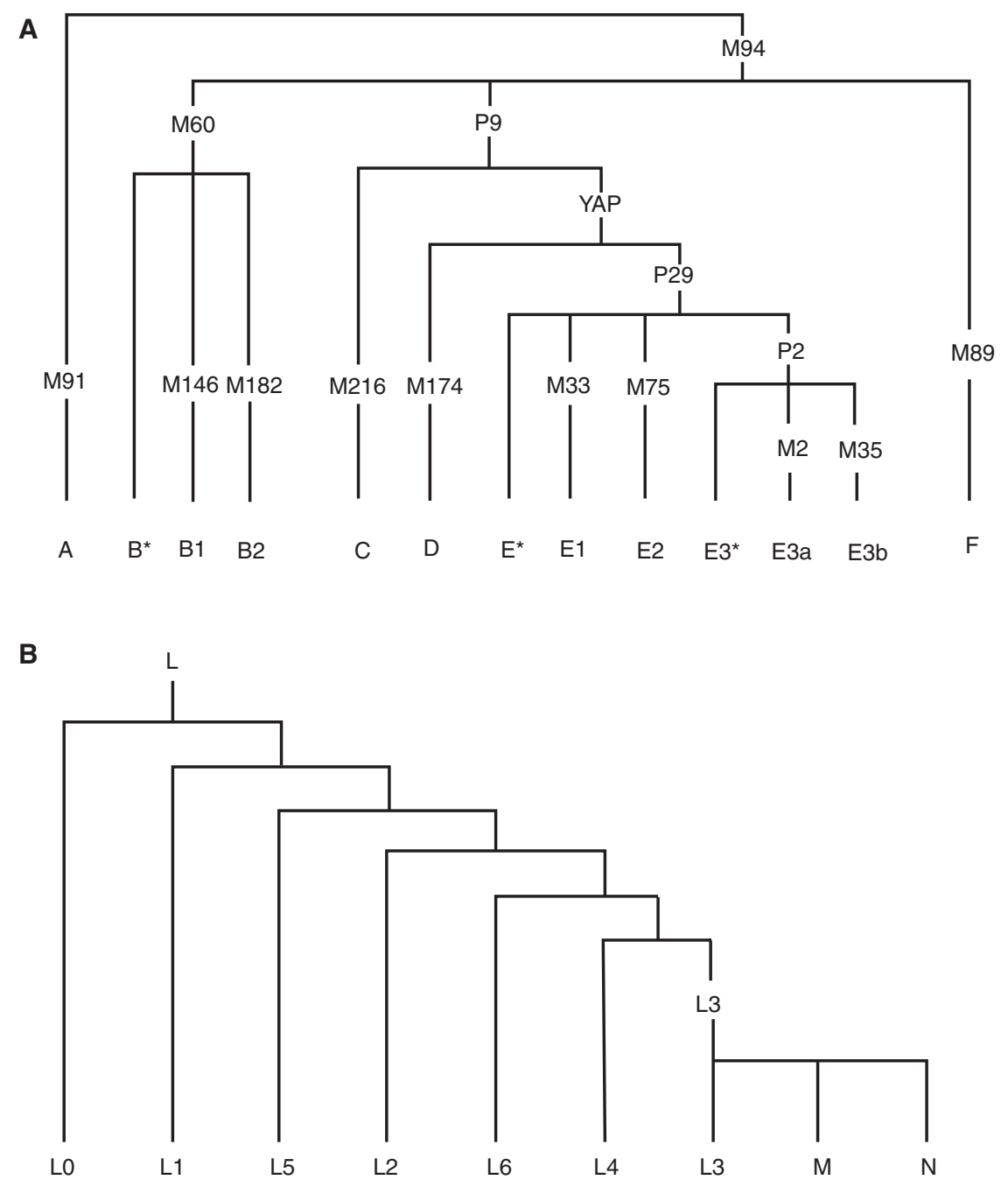

Figure 2. Evolutionary tree of Y chromosome and mtDNA haplogroups. (A) Nomenclature for major lineages of Y chromosome haplotypes. The M, P, and YAP labels leading to haplogroup/s are SNPs and indels that are used to define these haplogroups. Haplogroup F encompasses haplogroups F to T. Haplogroups A, B, and E are mainly found in Africa, whereas the rest are found mainly outside Africa. (B) Overview of mtDNA haplogroup phylogeny. In the mtDNA haplogroup nomenclature, the letter names of the haplogroups run from A to Z, with further subdivisions using numbers ( from 0 ) and lowercase letters (from a). The naming was done in the order of their discovery and does not reflect the actual genetic relationships. Haplogroup $\mathrm{M}$ and $\mathrm{N}$ encompasses all of the haplogroups lettered A to Z excluding haplogroup L. Haplogroups L (L0-L6) are mainly found in Africa, whereas the rest are found mainly outside Africa (Richards et al. 1998; Macaulay et al. 1999; Quintana-Murci et al. 1999; Salas et al. 2002; Kivisild et al. 2004; Behar et al. 2008).

Comprehensive analysis of African genetic variation will help us address some of the outstanding questions about the origin of our species such as: (1) precisely where and when modern humans originated in Africa; (2) the number and age of ancestral structured populations in
Africa; (3) the age and direction of ancient migration events both within and out of Africa (e.g., we do not yet have a consensus from genetic studies on the timing and route/s modern humans took out of Africa to populate the rest of the globe); and, (4) determination of the ar- 
F. Gomez et al.

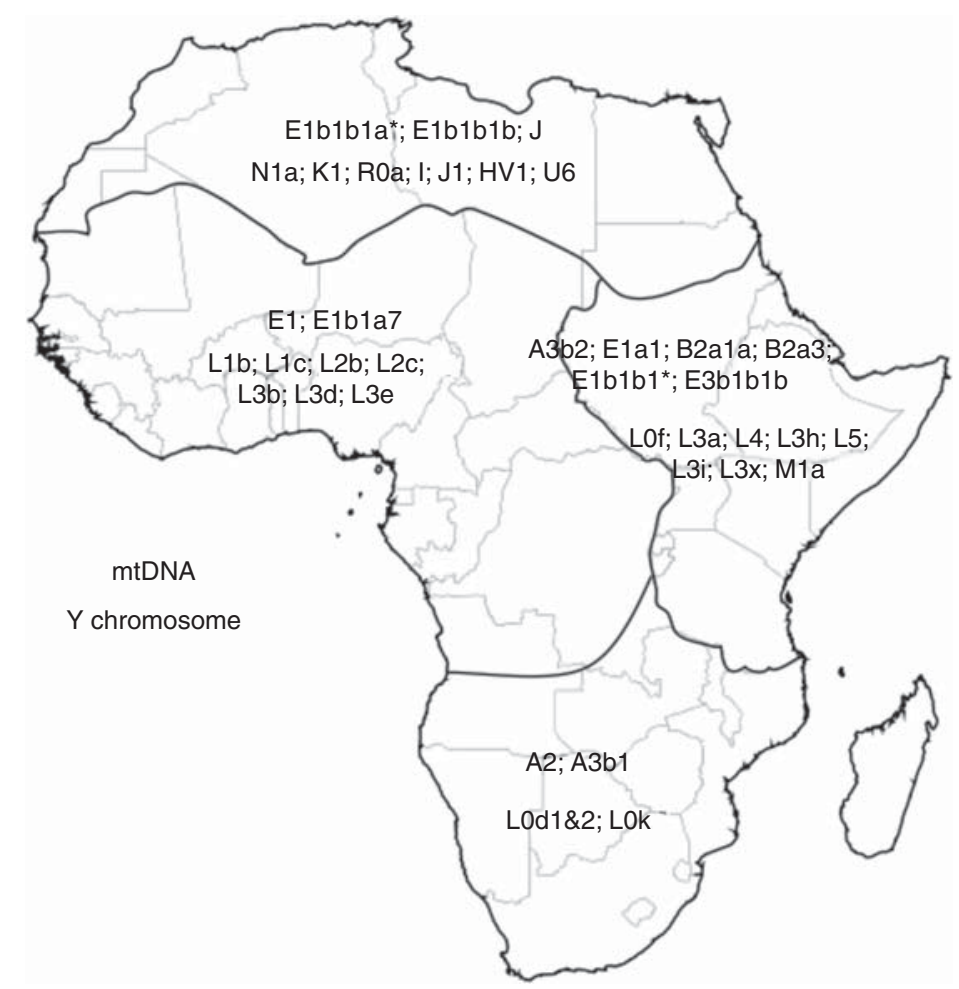

Figure 3. Distribution of mtDNA and Y chromosome haplogroups across Africa. The black lines represent the approximate geographical boundaries of the distribution of each haplogroup cluster, with each of the clusters predominantly observed in the demarcated regions.

chaic source population(s) from which genetic introgression occurred into African populations and when these events took place.

\section{DARWINIAN SELECTION AND GENETIC VARIATION}

Demographic events such as those described above, that is changes in population size, shortand long-range migrations, and admixture or gene flow from one population to another, influence the levels and patterns of genetic variation across the genome (Campbell and Tishkoff 2008). In addition to demography, natural selection, recombination and mutation, which take place in specific parts of the genome, can also influence genetic variability.

Natural selection occurs when the fitness effects of genotypes are unequal (Nielsen 2005). For example, a beneficial genetic variant is likely to increase in frequency in a population over time because of positive selection. Likewise, if a genetic variant is deleterious, it may be selected against and its frequency in a population will decrease over time. The occurrence of natural selection can thus create substantial differences in the patterns of genetic variation between human populations (Aquadro et al. 2001). Identifying loci that exhibit patterns of genetic variation that are indicative of natural selection is, therefore, important because these loci are likely to be regions of the genome that are, or have been, functionally important and play a role in adaptation to local environments. Furthermore, understanding which regions of the genome have been subject to natural selection will aid in the identification of genetic variation that contributes to phenotypic variation among human populations, including disease susceptibility (Ronald and Akey 2005). Here, 
we discuss results of several studies of local adaptation to distinct environments and diets within Africa.

\section{Lactase Persistence}

Adult mammals lose the ability to effectively digest lactose, the main carbohydrate in milk, after weaning. The inability to digest lactose is a result of decreased production of the enzyme lactase-phlorizin hydrolase, or lactase (Swallow 2003; Ingram et al. 2009). Individuals who are unable to digest lactose have what is called the "lactase nonpersistent" (LNP) trait. Although the LNP trait was once considered to be pathologic, it is now well understood that this trait is "ancestral" (i.e., all ancestors of modern humans had this condition) and widespread among human populations (Auricchio et al. 1963; Newcomer et al. 1983; Segal et al. 1983). Individuals with the "lactase persistent" (LP) trait continue to have high levels of lactase production into adulthood. The LP trait is common only in populations whose ancestors practiced cattle domestication or pastoralism (Ingram et al. 2009). For example, LP occurs at high frequencies in northern European dairying populations (e.g., Finns, Swedes, and Danes), and decreases in frequency in southern Europe, the Middle East, and in most of Asia (Durham 1991). LP is also found to be common in some pastoral populations in Africa (Tishkoff et al. 2007). Thus, it has been hypothesized that LP is an adaptive trait in human populations that practice cattle domestication and dairying (Swallow 2003).

In Europe, a common regulatory variant outside of the gene that encodes lactase (LCT) has been identified as being strongly associated with the LP trait (Enattah et al. 2002; Ingram et al. 2007; Tishkoff et al. 2007; Enattah et al. 2008). Several studies also suggest that this variant is causal and is a target of recent natural selection (Enattah et al. 2002; Poulter et al. 2003; Bersaglieri et al. 2004; Coelho et al. 2005). This suggestion is based on several lines of evidence. First, experiments in small intestine cell lines suggest that the European mutation increases the expression of the lactase gene and causes an increase in the production of the lactase enzyme (Enattah et al. 2002; Olds and Sibley 2003; Troelsen et al. 2003; Lewinsky et al. 2005). Additionally, several different tests indicate that the LCT locus has experienced recent strong natural selection (Poulter et al. 2003; Bersaglieri et al. 2004; Coelho et al. 2005). These studies have identified unexpectedly long genomic regions of genetic similarity flanking the LCT locus, which is a signature of recent positive selection. When positive selection causes a variant or variants to increase in frequency, the selected variant will cause neighboring genetic variation to "hitchhike" as the selected variant increases in frequency, thereby causing large tracks of identical sequences surrounding the variant under selection. This genetic feature has been identified in many European individuals with the regulatory variant who have the LP trait (Poulter et al. 2003). Finally, the estimated age of the European LP-associated variant is between $\sim 20,000$ and $\sim 2000$ years ago (Bersaglieri et al. 2004; Coelho et al. 2005; Tishkoff et al. 2007). These dates are consistent with the origins of dairy farming in southwest Asia that have been estimated from the archaeological record at 8-9 kya (Evershed et al. 2008).

Although this is a convincing example of gene/culture co-evolution in Europe, the genetic basis of the LP phenotype was largely unknown in Africa for many years. Previous studies (Mulcare et al. 2004) indicated that the European regulatory variant was noticeably absent in many African populations, including populations that have a history of pastoralism and drinking milk. This observation called into question whether the European variant is truly the causal variant for lactase persistence (Ingram et al. 2007). However, genotype/phenotype association studies of LP in Africa (Swallow 2003; Tishkoff et al. 2007) have identified three novel variants upstream of LCT, near the European variant, that are significantly associated with LP in African populations. All three of the African sites enhance the expression of LCT (Tishkoff et al. 2007; Enattah et al. 2008), and the most common of the three African mutations also shows strong evidence of recent strong positive selection. The estimated age of 
F. Gomez et al.

this African variant is $\sim 3000-7000$ years, consistent with the introduction of cattle domestication south of the Saharan Desert within the past $\sim 5500$ years (Tishkoff et al. 2007). Together, these examples from Europe and Africa show us that strong selective pressure can increase the frequency of numerous rare mutations that arise independently and regulate lactase gene expression where people practice dairying. The occurrence of multiple mutations that evolved under similar selection pressures is a good example of convergent evolution in several different human populations.

\section{Malaria}

Examination of population-level genetic variation and recent natural selection caused by infectious diseases can help us understand differences in disease susceptibility and incidence, and why some genetic variants, especially those that are potentially deleterious, are common in specific populations. Malaria is one such example that has had an important impact on patterns of human genetic variation and the geographic distribution of a number of genetic disorders (Fortin et al. 2002).

Malaria is a parasitic disease caused by species in the genus Plasmodium. There are several Plasmodium species that infect humans, including P. falciparum, P. ovale, P. malariae, and $P$. vivax. A large number of genetic variants that are associated with malaria-protective phenotypes have been identified and many of them cause serious disease (Ko et al. 2012; Gomez et al. 2013a). For example, variants associated with hemoglobinopathies, $\alpha$ and $\beta$ thalassemias, and the structural hemoglobin variants $S, C$, and $\mathrm{E}$, are classic examples of deleterious genetic variants that nevertheless confer protection from malaria (Weatherall 2001; Gomez et al. 2013b). Early studies of thalassemias (Haldane 1949; Flint et al. 1986) noted that these diseases have a geographic distribution that coincides with $P$. falciparum endemicity. In what is now called the "malaria hypothesis," JBS Haldane suggested that the genetic variants responsible for the thalassemias may be maintained in some human populations because of an advantage associated with malaria resistance (Haldane 1949). In a recent analysis, Piel et al. (2010) revisited the global distribution of sickle cell anemia, a disease caused by a mutation in the $\beta$-globin gene (HbS). They showed strong geographical correlation between $\mathrm{HbS}$ allele frequency and malaria endemicity in Africa (Fig. 4), consistent with the malaria hypothesis.

Additional studies of other genes have shed further light on our understanding of the coevolution of humans and P. falciparum, and provide evidence of recent natural selection in the human genome. For example, studies of genetic variation at G6PD (glucose-6-phosphate dehyrogenase), a gene that is known to harbor mutations associated with G6PD enzyme deficiency and protection from $P$. falciparum infection, have revealed signatures of genetic variation consistent with recent natural selection (Tishkoff et al. 2001; Saunders et al. 2002; Verrelli et al. 2002; Sabeti et al. 2006). Among the $G 6 P D$ variants that are associated with protection from malaria, the A-variant is most common in sub-Saharan Africa. Several studies, in African and non-African populations (Tishkoff et al. 2001; Sabeti et al. 2002; Saunders et al. 2002; Verrelli et al. 2002), have identified signatures of recent natural selection acting on the Avariant and inferred the TMRCA for this variant to range from $\sim 1200$ to $12,000 \mathrm{ya}$, which is consistent with the idea that selective pressures caused by malaria increased in African populations as population densities increased after the introduction of domesticated plants and animals (Tishkoff et al. 2001).

\section{Kidney Disease}

In the United States, diseases like type 2 diabetes mellitus, hypertension, and prostate cancer are known to be more common in African Americans than European Americans (Landis et al. 1999; Brancati et al. 2000; Ong et al. 2007). This disparity in disease occurrence suggests that genetic factors mediating disease risk, together with environmental factors, may differ among European and African descent populations (Hunter 2005; Yang et al. 2005; Cooper 2013). It has been proposed that genetic risk 

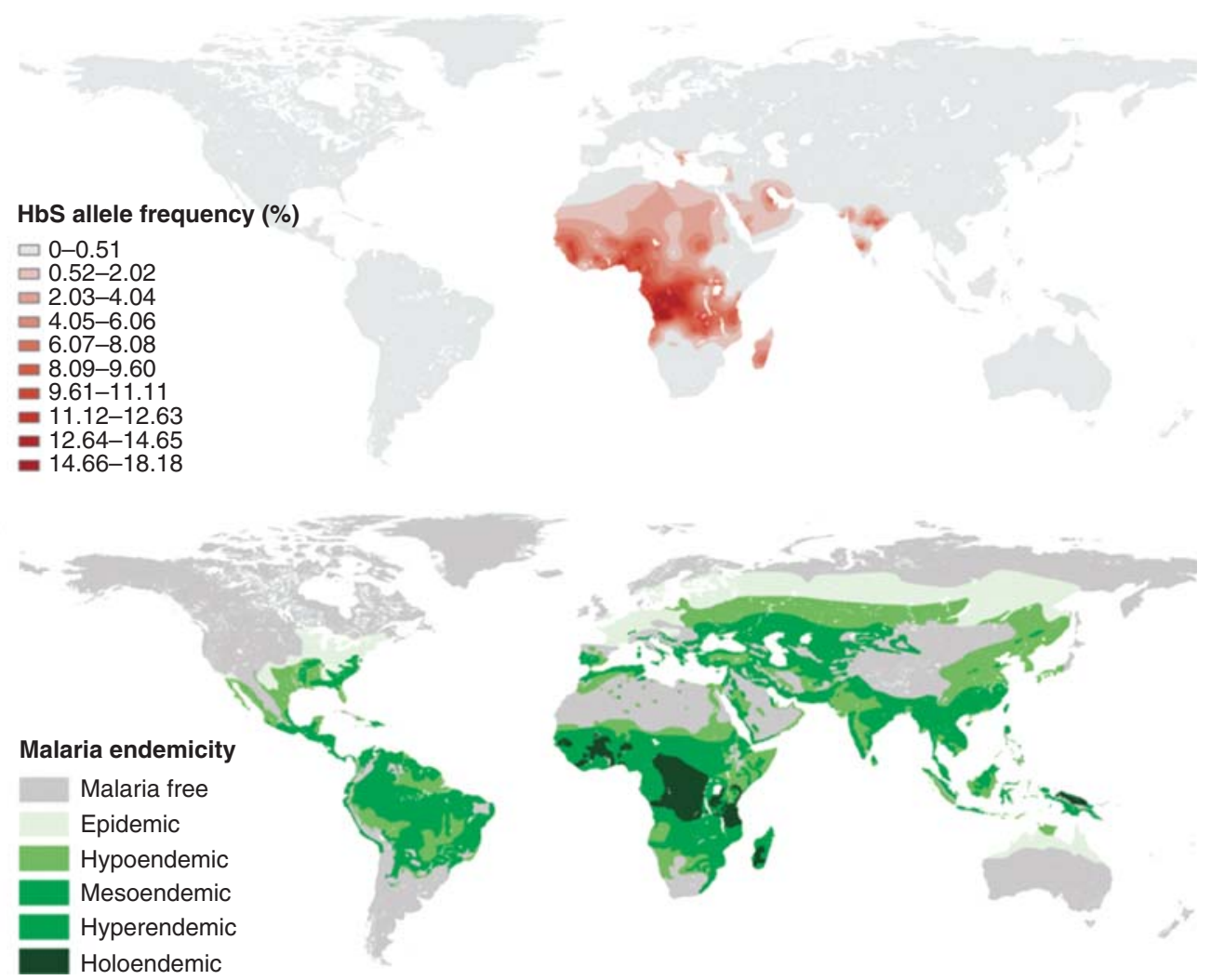

Figure 4. Global distribution of the HbS sickle cell anemia allele compared to the historic geographic distribution of malaria. (Top) Global distribution of HbS allele frequency predicted from Bayesian geostatistical modeling. (Bottom) Historical map of malaria endemicity. The classes are defined by $\operatorname{PfPr}_{2-10}\left(\mathrm{PfPr}_{2-10}=\right.$ proportion of 2- to 10-year olds with confirmed blood stage asexual parasites): malaria free, $P f \mathrm{Pr}_{2-10}=0$; epidemic, ${ }_{P f P r} \operatorname{Pr}_{20} \approx 0$; hypoendemic, $P f \operatorname{Pr}_{2-10}<0.10$; mesoendemic, $P f \operatorname{Pr}_{2-10} \geq 0.10$ and $<0.50$; hyperendemic, $\operatorname{PfPr}_{2-10} \geq 0.50$ and $<0.75$; holoendemic, $P f \mathrm{Pr}_{0-1}-1 \geq 0.75$ (this class was measured in children ages $0-$ 1) (From Piel et al. (2010); reproduced, with express permission, from Nature Publishing Group (C) 2010.)

factors could be more common in African populations because they may have been adaptive in past African environments but increase risk for disease in today's Western environment (Campbell and Tishkoff 2008).

One example of such a disease at high prevalence in African Americans is chronic kidney disease (CKD). In 2009, the mortality rate of African Americans with CKD was significantly higher than the mortality rate in European Americans and patients of other ethnicities (United States Renal Data System 2011). Additionally, in 2009, end-stage renal disease (ESRD), a serious complication of CKD in which a patient has complete or near complete loss of renal function and requires either frequent dialysis or a kidney transplant, occurred at a rate that is 3.5 times greater in African Americans than European Americans (United States Renal Data System 2011). There are many different causes of CKD; however, the primary proximal causes include diabetes and hypertension. There are also inherited forms of CKD; some of these include polycystic kidney disease (PKD), focal segmental glomerulosclerosis (FSGS), and pediatric nephrotic syndrome (Friedman and Pollak 2011).

Most African Americans have mixed ancestry originating from Africa and Europe; studies have inferred the average amount of European 
F. Gomez et al.

ancestry in African Americans to be $~ 20 \%$ and the remainder to be predominantly of western and central African origin (Smith et al. 2004; Bryc et al. 2009; Tishkoff et al. 2009). It should be noted, however, that there is substantial variation in the level of African ancestry in individual African Americans. The proportion of African ancestry in a given individual can range from $99 \%$ to $1 \%$. Additionally, the level of African or European ancestry in African Americans not only varies by individual but also by genomic region (Bryc et al. 2009). To identify genetic factors mediating disease predisposition in populations of recent African descent, like African Americans, a number of different approaches have been employed (Dong et al. 1999; Smith et al. 2004; Malhotra et al. 2005; Leak et al. 2007; Adeyemo et al. 2009; Sale et al. 2009; McDonough et al. 2011). One of these, called admixture mapping, is based on the premise that if a trait or disease of interest has a different prevalence in the parental populations prior to admixture, then it is likely that the genetic variation causing the disease or trait of interest in the admixed population is associated with chromosomal segment(s) derived from that parental population where the disease or trait is more prevalent (Winkler et al. 2010).

The identification of genetic risk factors for CKD in African Americans is an important example of the success of admixture mapping (Kao et al. 2008; Kopp et al. 2008; Genovese et al. 2010; Tzur et al. 2010). In 2008, two studies independently identified MYH9 as a candidate locus associated with CKD or ESRD in African Americans. Kopp et al. (2008) analyzed FSGS African-American cases and controls and showed a significant association on chromosome 22 near the MYH9 locus. They also found a marked increase of African ancestry in FSGS cases. Because MYH9 is expressed in the kidney, the authors considered this to be a good causal candidate gene. In the second study, Kao et al. (2008) also used admixture mapping to search for genetic variants associated with CKD and identified a single location significantly associated with disease on chromosome 22 in a population of nondiabetic ESRD patients. They also showed that the amount of European ancestry in the ESRD cases at that region was significantly lower than the average across the genome. Similar to Kopp et al. (2008), Kao et al. (2008) identified MYH9 as the likely candidate gene responsible for the strong association signal, given the expression patterns of MYH9 in the kidney.

Following publication of these two papers, numerous studies were conducted to find the functional variants responsible for these admixture signals (Kao et al. 2008; Kopp et al. 2008; Freedman et al. 2009a,b; Reeves-Daniel et al. 2010; Rosset et al. 2011; Freedman and Murea 2012). In 2010, two groups (Genovese et al. 2010; Tzur et al. 2010) used the data from the 1000 Genomes Project to identify potential functional variants that differ in frequency between Africans and Europeans near the MYH9 locus. Genovese et al. (2010) performed association tests of genome-wide variants with FSGS using African-American cases and controls (a genome wide association study or GWAS). They showed that the strongest signal with FSGS was not at MYH9 but at APOL1, which is a gene that is a short distance from MYH9. The strongest association signal was observed at a genetic variant termed $G_{1}$. When the authors controlled for the association of $G_{1}$ with FSGS they found a second associated allele that they termed $G_{2}$. The combined signal at $G_{1}$ and $G_{2}$ was 35 orders of magnitude greater than the signal found at MYH9. Tzur et al. (2010) also used the 1000 Genomes data to search for new variants near MYH9 that might be functional. They found four genetic variants that were potential candidates; two variants in APOL1 (also identified by Genovese et al. 2010), one in APOL3, located further upstream, and one in FOXRED2, located downstream from MYH9. They found that the $A P O L 1$ variants are more strongly associated with CKD than the MYH9 risk alleles in African-American and Hispanic-American ESRD cases.

In addition to the association study, Genovese et al. (2010) tested whether either the $G_{1}$ or $\mathrm{G}_{2}$ gene variants exhibited a signature of recent positive selection. The results of their analyses suggest that at $G_{1}$ there is a strong signal of recent positive selection and a weak, but noteworthy, signal of recent positive selection at $\mathrm{G}_{2}$. 
Because it is unlikely that $G_{1}$ and $G_{2}$ were positively selected for their deleterious role in the pathogenesis of kidney disease, Genovese et al. (2010), Tzur et al. (2010), and Oleksyk et al. (2010) speculated that these alleles must serve a separate beneficial role in an African environment. In Africa, APOL1 is an important factor in resistance to infection from Trypanosoma brucei brucei, one of the trypanosomes that cause African sleeping sickness. Genovese et al. hypothesized that this function may be the underlying reason for the apparent recent positive selection at APOL1 (also see Oleksyk et al. 2010; Tzur et al. 2010). To test this hypothesis, Genovese et al. (2010), examined whether the $G_{1}$ or $\mathrm{G}_{2}$ alleles influence the resistance phenotypes conferred by APOL1 during infection caused by three subspecies of Trypanosoma brucei (Trypanosoma brucei brucei, Trypanosoma brucei rhodesiense, and Trypanosoma brucei gambiens). They showed that the $\mathrm{G}_{1}$ and $\mathrm{G}_{2}$ alleles effectively killed $>60 \%$ of the T.b.rhodesiense samples and suggested that the signature of selection observed at these variants may be the result of the selective advantage conferred against Trypanosoma infection. However, it should be noted that T.b.rhodesiense is presently found in East Africa and the signature of selection identified by Genovese et al. was found in West African populations. Additionally, Tzur et al. (2010) did not find the APOL1 variants in people from Ethiopia, which implies that the $G_{1}$ and $G_{2}$ alleles may not be common in East African populations. The absence of the $G_{1}$ and $G_{2}$ variants in Ethiopia is difficult to reconcile with the observation that that $\mathrm{G}_{1}$ and $\mathrm{G}_{2}$ are most effective at killing Tryanosoma species that are common in East Africa. However, Genovese et al. (2010) suggest that changes in Trypanosoma biology and distribution and/or human migration could explain the lack of correlation between parasite range and the distribution of the $G_{1}$ and $G_{2}$ alleles today. They also propose that the $\mathrm{G}_{1} / \mathrm{G}_{2}$ variants at APOL1 could play a role in immunity to other pathogens common in western Africa.

More recently, Ko et al. (2013) further examined genetic variation at APOL1 and showed that the $\mathrm{G}_{2}$ variant has a similar frequency across diverse African populations $(3 \%-8 \%)$ and that the $G_{1}$ variant is only common in the Yoruba population $(39 \%)$. These authors identified another variant, termed $G_{3}$, which has a more widespread distribution than the $G_{1}$ variant, and showed a signature of recent natural selection in a West African Fulani population. Further studies of $G_{1} / G_{2}$ allele frequencies in diverse African populations and additional tests of recent natural selection are necessary to better understand the evolutionary history of this locus and how selection has influenced allele frequencies at $A P O L 1$. It is also important to note that the functional mechanism(s) underlying the association of $G_{1} / G_{2}$ with CKD is currently unknown. In addition to further studies of kidney disease in African populations, additional studies are also needed to demonstrate the functional roles that the $G_{1}, G_{2}$, and $G_{3}$ variants play in infectious disease and kidney disease.

The identification of regions in African genomes that are recent targets of natural selection has resulted in important insights into the genetic basis of many pathological and nonpathologic phenotypes common in African populations. However, despite the growth of evolutionary studies to understand the prevalence of disease phenotypes, there is a general lack of epidemiological studies that help us understand the prevalence of noncommunicable diseases in African countries and how genetic variation plays a role in presence and prevalence of these diseases. Dalal et al. (2011) reported that in 2004 about one-quarter of all deaths in sub-Saharan Africa were caused by noncommunicable diseases, and they estimate that by 2030 noncommunicable diseases will increase to $46 \%$ of all deaths in sub-Saharan Africa. Unfortunately, their review of the literature suggests that community-based epidemiologic studies of noninfectious diseases, such as diabetes, cardiovascular disease, and obesity, are lacking in many African nations compared to the focus on maternal-child health and infectious diseases. Thus, despite the current shift in the prevalence of noninfectious diseases, we are currently ill-equipped to describe who is being affected and what the genetic and environmental risk factors that contribute to noncommunicable disease susceptibility in Africa are. 
F. Gomez et al.

In the coming decades, it will be crucial to focus on the prevalence of noninfectious diseases in African countries and to understand what genetic variants predispose African people to conditions like obesity and cardiovascular disease. The effort to understand the genetic basis of complex noninfectious diseases in Africa should be twofold-our efforts should be placed on large-scale studies of both families and unrelated people. These two approaches will allow us to better characterize how disease-causing variants are distributed among diverse populations, and family-based studies will also help us to identify rare genetic variants that are difficult to identify in studies of unrelated people. Comparison of African populations and those within the African diaspora across diverse environments may also help to disentangle genetic and environmental effects on variable phenotypes and disease risk. These efforts will help to elucidate factors contributing to complex diseases in Africa and may also elucidate the genetic basis of these conditions in populations that have recent African admixture, like African Americans, Hispanics, and peoples of the Caribbean.

\section{CONCLUSIONS}

The pattern of genetic variation observed at mtDNA, Y chromosome, and autosomal loci in African populations reflects the demographic history of these populations. These data indicate high levels of genetic diversity within and between African populations, and also show that the current pattern of genetic variation in Africa is a result of both ancient and recent migration and admixture events.

The genomes of Africans have also been impacted by natural selection, sometimes resulting in prevalence of genetic variants that cause disease. Studies of natural selection in African populations show that functionally important genetic variants may be common but geographically restricted within Africa because of local adaptation to a particular lifestyle or environment. Also, many common variants that are adaptive because of protection from an infectious disease may also result in susceptibility to a different, possibly noninfectious, disease in populations of recent African origin. This observation points to the importance of including ethnically diverse Africans in human genetic studies because these populations represent an important component of human genomic variation, and data from African populations help us to understand the context in which some genetic variants were selected.

Going forward, as the cost of whole genome sequencing decreases, it will become feasible to conduct large-scale genomic sequencing studies across ethnically diverse Africans. These data are necessary to understand the genetic basis of complex disease in Africa and also the genetic basis of complex disease in populations like African Americans. Currently, most large-scale studies that seek to identify genetic variants that are associated with complex disease risk are heavily biased toward the identification of genetic variants initially discovered in European populations. Large-scale sequencing studies in African populations will identify new non-European variants that can be added to the repertoire of variation that is included in large association studies. The inclusion of a more diverse panel of variants will increase what we know about the genetic basis of complex diseases because new variants will allow us to search for associations among sites that are common in people from many different ethnic backgrounds. These studies will shed light on modern human origins, African and African-American population history, and the genetic basis of nonpathologic traits as well as traits that affect disease susceptibility.

\section{REFERENCES}

${ }^{*}$ Reference is also in this collection.

The 1000 Genomes Project Consortium. 2010. A map of human genome variation from population-scale sequencing. Nature 467: 1061-1073.

Abi-Rached L, Jobin MJ, Kulkarni S, McWhinnie A, Dalva K, Gragert L, Babrzadeh F, Gharizadeh B, Luo M, Plummer FA, et al. 2011. The shaping of modern human immune systems by multiregional admixture with archaic humans. Science 334: 89-94.

Adeyemo AA, Chen G, Chen Y, Rotimi C. 2005. Genetic structure in four West African population groups. BMC Genet 6: 38. 
Adeyemo A, Gerry N, Chen G, Herbert A, Doumatey A, Huang H, Zhou J, Lashley K, Chen Y, Christman M, et al. 2009. A genome-wide association study of hypertension and blood pressure in African Americans. PLoS Genet 5: e1000564.

Alves-Silva J, da Silva Santos M, Guimaraes PE, Ferreira AC, Bandelt HJ, Pena SD, Prado VF. 2000. The ancestry of Brazilian mtDNA lineages. Am J Hum Genet 67: 444461.

Ambrose SH. 1982. HHistorical and linguistic reconstructions in East Africa; The archeological evidence. In The archeological and linguistic reconstruction of African History (ed. Ehret C, Posnansky ME). Boston University African Studies Center, Berkeley, CA.

Aquadro CF, Bauer DuMont V, Reed FA. 2001. Genomewide variation in the human and fruitfly: A comparison. Curr Opin Genet Dev 11: 627-634.

Atkinson QD, Gray RD, Drummond AJ. 2008. mtDNAvariation predicts population size in humans and reveals a major Southern Asian chapter in human prehistory. Mol Biol Evol 25: 468-474.

Atkinson QD, Gray RD, Drummond AJ. 2009. Bayesian coalescent inference of major human mitochondrial DNA haplogroup expansions in Africa. Proc Biol Sci 276: $367-$ 373.

Atzmon G, Hao L, Pe'er I, Velez C, Pearlman A, Palamara PF, Morrow B, Friedman E, Oddoux C, Burns E, et al. 2010. Abraham's children in the genome era: Major Jewish diaspora populations comprise distinct genetic clusters with shared Middle Eastern ancestry. Am J Hum Genet 86: 850-859.

Auricchio S, Rubino A, Landolt M, Semenza G, Prader A. 1963. Isolated intestinal lactase deficiency in the adult. Lancet 2: 324-326.

Bandelt HJ, Forster P, Sykes BC, Richards MB. 1995. Mitochondrial portraits of human populations using median networks. Genetics 141: 743-753.

Bandelt HJ, Alves-Silva J, Guimaraes PE, Santos MS, Brehm A, Pereira L, Coppa A, Larruga JM, Rengo C, Scozzari R, et al. 2001. Phylogeography of the human mitochondrial haplogroup L3e: A snapshot of African prehistory and Atlantic slave trade. Ann Hum Genet 65: 549-563.

Barthelme JW. 1977. Holocene sites north-east of Lake Turkana: Preliminary report. Azania 12: 33-41.

Batini C, Coia V, Battaggia C, Rocha J, Pilkington MM, Spedini G, Comas D, Destro-Bisol G, Calafell F. 2007. Phylogeography of the human mitochondrial L1c haplogroup: Genetic signatures of the prehistory of Central Africa. Mol Phylogenet Evol 43: 635-644.

Batini C, Lopes J, Behar DM, Calafell F, Jorde LB, van der Veen L, Quintana-Murci L, Spedini G, Destro-Bisol G, Comas D. 2011. Insights into the demographic history of African Pygmies from complete mitochondrial genomes. Mol Biol Evol 28: 1099-1110.

Batzer MA, Deininger PL. 2002. Alu repeats and human genomic diversity. Nat Rev Genet 3: 370-379.

Behar DM, Villems R, Soodyall H, Blue-Smith J, Pereira L, Metspalu E, Scozzari R, Makkan H, Tzur S, Comas D, et al. 2008. The dawn of human matrilineal diversity. Am J Hum Genet 82: 1130-1140.
Behar DM, Yunusbayev B, Metspalu M, Metspalu E, Rosset S, Parik J, Rootsi S, Chaubey G, Kutuev I, Yudkovsky G, et al. 2010. The genome-wide structure of the Jewish people. Nature 466: 238-242.

Beleza S, Gusmao L, Amorim A, Carracedo A, Salas A. 2005. The genetic legacy of western Bantu migrations. Hum Genet 117: 366-375.

Berniell-Lee G, Calafell F, Bosch E, Heyer E, Sica L, Mouguiama-Daouda P, van der Veen L, Hombert JM, Quintana-Murci L, Comas D. 2009. Genetic and demographic implications of the Bantu expansion: Insights from human paternal lineages. Mol Biol Evol 26: 1581-1589.

Bersaglieri T, Sabeti PC, Patterson N, Vanderploeg T, Schaffner SF, Drake JA, Rhodes M, Reich DE, Hirschhorn JN. 2004. Genetic signatures of strong recent positive selection at the lactase gene. Am J Hum Genet 74: 1111-1120.

Blench R. 1993. Recent developments in African language classification and their implications for prehistory. In The archaeology of Africa: Food, metals and towns (ed. Shaw PST, Andah B, Okpoko A), pp. 71-103. Routledge, London.

Blench R. 2006. Archaeology, language, and the African past. AltaMira, Lanham, MD.

Bower JRF. 1973. Seronera: Excavations at a stone bowl site in the Serengeti National Park, Tanzania. Azania 8: 71104.

Brancati FL, Kao WH, Folsom AR, Watson RL, Szklo M. 2000. Incident type 2 diabetes mellitus in African American and white adults: The Atherosclerosis Risk in Communities Study. JAMA 283: 2253-2259.

Bray SM, Mulle JG, Dodd AF, Pulver AE, Wooding S, Warren ST. 2010. Signatures of founder effects, admixture, and selection in the Ashkenazi Jewish population. Proc Natl Acad Sci 107: 16222-16227.

Bryc K, Auton A, Nelson MR, Oksenberg JR, Hauser SL, Williams S, Froment A, Bodo JM, Wambebe C, Tishkoff SA, et al. 2009. Genome-wide patterns of population structure and admixture in West Africans and African Americans. Proc Natl Acad Sci 107: 786-791.

Bryc K, Auton A, Nelson MR, Oksenberg JR, Hauser SL, Williams S, Froment A, Bodo JM, Wambebe C, Tishkoff SA, et al. 2010. Genome-wide patterns of population structure and admixture in West Africans and African Americans. Proc Natl Acad Sci 107: 786-791.

Butzer KW. 1981. Rise and fall of Axum, Ethiopia: A geoarchaeological interpretation. Am. Antiq. 46: 471-495.

Butzer KW, Brown FH, Thurber DL. 1969. Horizontal sediments of the lower Omo Basin: The Kibish formation. Quarternaria 11: 15-29.

Campbell MC, Tishkoff SA. 2008. African genetic diversity: Implications for human demographic history, modern human origins, and complex disease mapping. Annu Rev Genomics Hum Genet 9: 403-433.

Cann RL, Stoneking M, Wilson AC. 1987. Mitochondrial DNA and human evolution. Nature 325: 31-36.

Cann HM, de Toma C, Cazes L, Legrand MF, Morel V, Piouffre L, Bodmer J, Bodmer WF, Bonne-Tamir B, Cambon-Thomsen A, et al. 2002. A human genome diversity cell line panel. Science 296: 261-262.

Castri L, Tofanelli S, Garagnani P, Bini C, Fosella X, Pelotti S, Paoli G, Pettener D, Luiselli D. 2009. mtDNA variability 


\section{F. Gomez et al.}

in two Bantu-speaking populations (Shona and Hutu) from Eastern Africa: Implications for peopling and migration patterns in sub-Saharan Africa. Am J Phys Anthropol 140: 302-311.

Cavalli-Sforza LL. 1994, The history and geography of human genes. Princeton University Press, Princeton, NJ.

Cerny V, Hajek M, Bromova M, Cmejla R, Diallo I, Brdicka R. 2006. MtDNA of Fulani nomads and their genetic relationships to neighboring sedentary populations. Hum Biol 78: 9-27.

Cerny V, Mulligan CJ, Ridl J, Zaloudkova M, Edens CM, Hajek M, Pereira L. 2008. Regional differences in the distribution of the sub-Saharan, West Eurasian, and South Asian mtDNA lineages in Yemen. Am J Phys Anthropol 136: 128-137.

Cerny V, Fernandes V, Costa MD, Hajek M, Mulligan CJ, Pereira L. 2009. Migration of Chadic-speaking pastoralists within Africa based on population structure of Chad Basin and phylogeography of mitochondrial L3f haplogroup. BMC Evol Biol 9: 63.

Chen YS, Torroni A, Excoffier L, Santachiara-Benerecetti AS, Wallace DC. 1995. Analysis of mtDNA variation in African populations reveals the most ancient of all human continent-specific haplogroups. Am J Hum Genet 57: 133-149.

Chen YS, Olckers A, Schurr TG, Kogelnik AM, Huoponen $\mathrm{K}$, Wallace DC. 2000. mtDNA variation in the South African Kung and Khwe-and their genetic relationships to other African populations. Am J Hum Genet 66: 1362 1383.

Coelho M, Luiselli D, Bertorelle G, Lopes AI, Seixas S, Destro-Bisol G, Rocha J. 2005. Microsatellite variation and evolution of human lactase persistence. Hum Genet 117: 329-339.

Coelho M, Sequeira F, Luiselli D, Beleza S, Rocha J. 2009. On the edge of Bantu expansions: mtDNA, Y chromosome and lactase persistence genetic variation in southwestern Angola. BMC Evol Biol 9: 80.

Coia V, Destro-Bisol G, Verginelli F, Battaggia C, Boschi I, Cruciani F, Spedini G, Comas D, Calafell F. 2005. Brief communication: mtDNA variation in North Cameroon: Lack of Asian lineages and implications for back migration from Asia to sub-Saharan Africa. Am J Phys Anthropol 128: 678-681.

Compton JS. 2011. Pleistocene sea-level fluctuations and human evolution on the southern coastal plain of South Africa. Quat Sci Rev 30: 506-527.

* Cooper RS. 2013. Race in biological and biomedical research. Cold Spring Harb Perspect Med 3: a008573.

Coudray C, Olivieri A, Achilli A, Pala M, Melhaoui M, Cherkaoui M, El-Chennawi F, Kossmann M, Torroni A, Dugoujon JM. 2008. The complex and diversified mitochondrial gene pool of Berber populations. Ann Hum Genet 73: 196-214.

Cox MP, Morales DA, Woerner AE, Sozanski J, Wall JD, Hammer MF. 2009. Autosomal resequence data reveal Late Stone Age signals of population expansion in subSaharan African foraging and farming populations. PLoS ONE 4: e6366.

Cruciani F, Santolamazza P, Shen P, Macaulay V, Moral P, Olckers A, Modiano D, Holmes S, Destro-Bisol G, Coia V, et al. 2002. A back migration from Asia to sub-Saharan
Africa is supported by high-resolution analysis of human Y-chromosome haplotypes. Am J Hum Genet 70: 11971214.

Cruciani F, Trombetta B, Sellitto D, Massaia A, Destro-Bisol G, Watson E, Beraud Colomb E, Dugoujon JM, Moral P, Scozzari R. 2010. Human Y chromosome haplogroup R-V88: a paternal genetic record of early mid Holocene trans-Saharan connections and the spread of Chadic languages. Eur J Hum Genet 18: 800-807.

Cruciani F, Trombetta B, Massaia A, Destro-Bisol G, Sellitto D, Scozzari R. 2011. A revised root for the human Y chromosomal phylogenetic tree: The origin of patrilineal diversity in Africa. Am J Hum Genet 88: 814-818.

Dalal S, Beunza JJ, Volmink J, Adebamowo C, Bajunirwe F, Nielekela M, Mozaffarian D, Fawzi W, Willett W, Adami HO, et al. 2011. Non-communicable diseases in sub-Saharan Africa: What we know now. Int J Epidemiol 40: 885-901.

Destro-Bisol G, Coia V, Boschi I, Verginelli F, Caglia A, Pascali V, Spedini G, Calafell F. 2004. The analysis of variation of mtDNA hypervariable region 1 suggests that Eastern and Western Pygmies diverged before the Bantu expansion. Am Nat 163: 212-226.

de Wit E, Delport W, Rugamika CE, Meintjes A, Moller M, van Helden PD, Seoighe C, Hoal EG. 2010. Genome-wide analysis of the structure of the South African coloured population in the Western Cape. Hum Genet 128: 145 153.

Distefano JA. 1990. Hunters or hunted? Towards a history of the Okiek of Kenya. Hist Africa 17: 41-57.

Dong Y, Zhu H, Sagnella GA, Carter ND, Cook DG, Cappuccio FP. 1999. Association between the C825T polymorphism of the G protein beta3-subunit gene and hypertension in blacks. Hypertension 34: 1193-1196.

Durham WH. 1991. Coevolution. Genes, culture and human diversity. Stanford University Press, Stanford, CT.

Ehret C. 1967. Cattle-keeping and milking in Eastern and Southern African History: The linguistic evidence. J African Hist 8: 1-17.

Ehret C. 1971. Southern Nilotic history: Linguistic approaches to the study of the past. Northwestern University Press, Evanston, IL.

Ehret C. 1993. Nilo-Saharans and the Saharo-Sudanese Neolithic. In The archaeology of Africa: Food, metals and towns (ed. Shaw PST, Andah B, Okpoko A), pp. 104-125. Routledge, London.

Ehret C. 1995. Reconstructing proto-Afroasiatic (Proto-Afrasian): Vowels, tone, consonants, and vocabulary. University of California Press, Berkeley, CA.

Ehret C. 1998. An African classical age: Eastern and Southern Africa in world history, 1000 B.C. to A.D. 400. University Press of Virginia, Charlottesville, VA.

Ehret C. 2001a. Bantu expansions: Re-envisioning a central problem of early African History. Int J African Historic Stud 34: 5-41.

Ehret C. 2001b. Historical-comparative reconstruction of Nilo-Saharan. Rüdiger Köppe Verlag, Cologne, Germany.

Ehret C. 2002. The civilizations of Africa: A history to 1800. University Press of Virginia, Charlottesville, VA.

Ehret C. 2006. Linguistic stratigraphies and Holocene history in Northeastern Africa. In Studies in African archae- 
ology, pp. 1019-1055. Poznan Archaeological Museum, Poznan, Poland.

Enattah NS, Sahi T, Savilahti E, Terwilliger JD, Peltonen L, Jarvela I. 2002. Identification of a variant associated with adult-type hypolactasia. Nat Genet 30: 233-237.

Enattah NS, Jensen TG, Nielsen M, Lewinski R, Kuokkanen M, Rasinpera H, El-Shanti H, Seo JK, Alifrangis M, Khalil IF, et al. 2008. Independent introduction of two lactasepersistence alleles into human populations reflects different history of adaptation to milk culture. Am J Hum Genet 82: 57-72.

Evershed RP, Payne S, Sherratt AG, Copley MS, Coolidge J, Urem-Kotsu D, Kotsakis K, Ozdogan M, Ozdogan AE, Nieuwenhuyse O, et al. 2008. Earliest date for milk use in the Near East and southeastern Europe linked to cattle herding. Nature 455: 528-531.

Excoffier L, Schneider S. 1999. Why hunter-gatherer populations do not show signs of pleistocene demographic expansions. Proc Natl Acad Sci 96: 10597-10602.

Flint J, Hill AV, Bowden DK, Oppenheimer SJ, Sill PR, Serjeantson SW, Bana-Koiri J, Bhatia K, Alpers MP, Boyce AJ, et al. 1986. High frequencies of $\alpha$-thalassaemia are the result of natural selection by malaria. Nature 321: 744750.

Fortin A, Stevenson MM, Gros P. 2002. Susceptibility to malaria as a complex trait: Big pressure from a tiny creature. Hum Mol Genet 11: 2469-2478.

Francalacci P, Morelli L, Angius A, Berutti R, Reinier F, Atzeni R, Pilu R, Busonero F, Maschio A, Zara I, et al. 2013 Low-pass DNA sequencing of 1200 Sardinians reconstructs European Y-chromosome phylogeny. Science 341: 565-569.

Freedman BI, Murea M. 2012. Target organ damage in African American hypertension: Role of APOL1. Curr Hypertens Rep 14: $21-28$.

Friedman DJ, Pollak MR. 2011. Genetics of kidney failure and the evolving story of APOL1. J Clin Invest 121: 3367 3374.

Freedman BI, Hicks PJ, Bostrom MA, Cunningham ME, Liu Y, Divers J, Kopp JB, Winkler CA, Nelson GW, Langefeld $\mathrm{CD}$, et al. 2009a. Polymorphisms in the non-muscle myosin heavy chain 9 gene (MYH9) are strongly associated with end-stage renal disease historically attributed to hypertension in African Americans. Kidney Int 75: $736-$ 745 .

Freedman BI, Kopp JB, Winkler CA, Nelson GW, Rao DC, Eckfeldt JH, Leppert MF, Hicks PJ, Divers J, Langefeld $\mathrm{CD}$, et al. 2009b. Polymorphisms in the nonmuscle myosin heavy chain 9 gene (MYH9) are associated with albuminuria in hypertensive African Americans: The HyperGEN study. Am J Nephrol 29: 626-632.

Genovese G, Friedman DJ, Ross MD, Lecordier L, Uzureau P, Freedman BI, Bowden DW, Langefeld CD, Oleksyk TK, Uscinski Knob AL, et al. 2010. Association of trypanolytic ApoL1 variants with kidney disease in African Americans. Science 329: 841-845.

Gomez F, Ko WY, Davis A, Tishkoff SA. 2013a. Malarial disease and human genetic variation: Evidence for natural selection at malaria susceptibility candidate loci. In Primates, pathogens and evolution (ed. Brinkworth J, Pechenkina E). Springer, New York.
Gomez F, Tomas G, Ko WY, Ranciaro A, Froment A, Ibrahim M, Lema G, Nyambo TB, Omar SA, Wambebe C, et al. 2013b. Patterns of nucleotide and haplotype diversity at ICAM-1 across global human populations with varying levels of malaria exposure. Hum Genet 132: 987-999.

Gonder MK, Mortensen HM, Reed FA, de Sousa A, Tishkoff SA. 2007. Whole-mtDNA genome sequence analysis of ancient African lineages. Mol Biol Evol 24: 757-768.

Gonzalez AM, Cabrera VM, Larruga JM, Tounkara A, Noumsi G, Thomas BN, Moulds JM. 2006. Mitochondrial DNA variation in Mauritania and Mali and their genetic relationship to other Western Africa populations. Ann Hum Genet 70: 631-657.

Graven L, Passarino G, Semino O, Boursot P, SantachiaraBenerecetti S, Langaney A, Excoffier L. 1995. Evolutionary correlation between control region sequence and restriction polymorphisms in the mitochondrial genome of a large Senegalese Mandenka sample. Mol Biol Evol 12: 334-345.

Green RE, Krause J, Briggs AW, Maricic T, Stenzel U, Kircher M, Patterson N, Li H, Zhai W, Fritz MH-Y, et al. 2011. A draft sequence of the Neandertal genome. Science 328: $710-722$.

Greenberg JH. 1963. The languages of Africa. Indiana University, Bloomington.

Greenberg JH. 1972. Linguistic evidence regarding Bantu origins. J Afr Hist 13: 189-216.

Haldane JBS. 1949. The rate of mutation in human genes. Hereditas 35: 267-273.

Hammer MF, Zegura SL. 2002. The human Y Chromosome haplogroup tree: Nomenclature and phylogeography of its major divisions. Annu Rev Anthropol 31: 303-321.

Hammer MF, Woerner AE, Mendez FL, Watkins JC, Wall JD. 2011. Genetic evidence for archaic admixture in Africa. Proc Natl Acad Sci 108: 15123-15128.

Harpending HC, Sherry ST, Rogers AR, Stoneking M. 1993. The genetic structure of ancient human populations. Curr Anthropol 34: 483-496.

Haspelmath M, Dryer MS, Gil D, Comrie B, eds. 2008. The world atlas of language structures online. Max Planck Digital Library, Munich.

Henn BM, Gignoux CR, Jobin M, Granka JM, Macpherson JM, Kidd JM, Rodriguez-Botigue L, Ramachandran S, Hon L, Brisbin A, et al. 2011. From the cover: Feature article: Hunter-gatherer genomic diversity suggests a southern African origin for modern humans. Proc Natl Acad Sci 108: 5154-5162.

Henn BM, Botigué LR, Gravel S, Wang W, Brisbin A, Byrnes JK, Fadhlaoui-Zid K, Zalloua PA, Moreno-Estrada A, Bertranpetit J, et al. 2012. Genomic ancestry of North Africans supports back-to-Africa migrations. PLoS Genet 8: e1002397.

Herrnstadt C, Elson JL, Fahy E, Preston G, Turnbull DM, Anderson C, Ghosh SS, Olefsky JM, Beal MF, Davis RE, et al. 2002. Reduced-median-network analysis of complete mitochondrial DNA coding-region sequences for the major African, Asian, and European haplogroups. Am J Hum Genet 70: 1152-1171.

Hofer T, Ray N, Wegmann D, Excoffier L. 2009. Large allele frequency differences between human continental groups are more likely to have occurred by drift during range 


\section{F. Gomez et al.}

expansions than by selection. Ann Hum Genet 73: 95108.

Hunter DJ. 2005. Gene-environment interactions in human diseases. Nat Rev Genet 6: 287-298.

Hunter-Zinck H, Musharoff S, Salit J, Al-Ali KA, Chouchane L, Gohar A, Matthews R, Butler MW, Fuller J, Hackett NR, et al. 2010. Population genetic structure of the people of Qatar. Am J Hum Genet 87: 17-25.

Ingman M, Kaessmann H, Paabo S, Gyllensten U. 2000. Mitochondrial genome variation and the origin of modern humans. Nature 408: 708-713.

Ingram CJ, Elamin MF, Mulcare CA, Weale ME, Tarekegn A, Raga TO, Bekele E, Elamin FM, Thomas MG, Bradman $\mathrm{N}$, et al. 2007. A novel polymorphism associated with lactose tolerance in Africa: Multiple causes for lactase persistence? Hum Genet 120: 779-788.

Ingram CJ, Mulcare CA, Itan Y, Thomas MG, Swallow DM. 2009. Lactose digestion and the evolutionary genetics of lactase persistence. Hum Genet 124: 579-591.

International HapMap C. 2005. A haplotype map of the human genome. Nature 437: 1299-1320.

Jackson BA, Wilson JL, Kirbah S, Sidney SS, Rosenberger J, Bassie L, Alie JA, McLean DC, Garvey WT, Ely B. 2005. Mitochondrial DNA genetic diversity among four ethnic groups in Sierra Leone. Am J Phys Anthropol 128: $156-$ 163.

Kao WH, Klag MJ, Meoni LA, Reich D, Berthier-Schaad Y, Li M, Coresh J, Patterson N, Tandon A, Powe NR, et al. 2008 MYH9 is associated with nondiabetic end-stage renal disease in African Americans. Nat Genet 40: 1185-1192.

Karafet TM, Mendez FL, Meilerman MB, Underhill PA, Zegura SL, Hammer MF. 2008. New binary polymorphisms reshape and increase resolution of the human Y chromosomal haplogroup tree. Genome Res 18: 830-838.

Kivisild T, Reidla M, Metspalu E, Rosa A, Brehm A, Pennarun E, Parik J, Geberhiwot T, Usanga E, Villems R. 2004. Ethiopian mitochondrial DNA heritage: Tracking gene flow across and around the gate of tears. Am J Hum Genet 75: 752-770.

Ko WY, Gomez F, Tishkoff S. 2012. Evolution of human erythrocyte-specific genes involved in malaria suscepti bility. In Rapidly evolving genes and genetic systems (ed. Singh RS, Xu J, Kulathinal RJ). Oxford University Press, Oxford.

Kopelman NM, Stone L, Wang C, Gefel D, Feldman MW, Hillel J, Rosenberg NA. 2009. Genomic microsatellites identify shared Jewish ancestry intermediate between Middle Eastern and European populations. BMC Genet 10: 80 .

Kopp JB, Smith MW, Nelson GW, Johnson RC, Freedman BI, Bowden DW, Oleksyk T, McKenzie LM, Kajiyama H, Ahuja TS, et al. 2008. MYH9 is a major-effect risk gene for focal segmental glomerulosclerosis. Nat Genet 40: $1175-1184$.

Krings M, Salem AE, Bauer K, Geisert H, Malek AK, Chaix L, Simon C, Welsby D, Di Rienzo A, Utermann G, et al. 1999. mtDNA analysis of Nile River Valley populations: A genetic corridor or a barrier to migration? Am J Hum Genet 64: 1166-1176.

Labuda D, Zietkiewicz E, Yotova V. 2000. Archaic lineages in the history of modern humans. Genetics 156: 799-808.
Lachance J, Vernot B, Elbers CC, Ferwerda B, Froment A, Bodo JM, Lema G, Fu W, Nyambo TB, Rebbeck TR, et al. 2012. Evolutionary history and adaptation from highcoverage whole-genome sequences of diverse African hunter-gatherers. Cell 150: 457-469.

Landis SH, Murray T, Bolden S, Wingo PA. 1999. Cancer statistics, 1999. CA Cancer J Clin 49: 8-31.

Leak TS, Keene KL, Langefeld CD, Gallagher CJ, Mychaleckyj JC, Freedman BI, Bowden DW, Rich SS, Sale MM. 2007. Association of the proprotein convertase subtilisin/kexin-type 2 (PCSK2) gene with type 2 diabetes in an African American population. Mol Genet Metab 92: $145-150$.

Leakey LSB. 1931. The Stone Age cultures of Kenya Colony. The University Press, Cambridge.

Lewinsky RH, Jensen TG, Moller J, Stensballe A, Olsen J, Troelsen JT. 2005. T-13910 DNA variant associated with lactase persistence interacts with Oct-1 and stimulates lactase promoter activity in vitro. Hum $\mathrm{Mol}$ Genet 14: 3945-3953.

Li JZ, Absher DM, Tang H, Southwick AM, Casto AM, Ramachandran S, Cann HM, Barsh GS, Feldman M, Cavalli-Sforza LL, et al. 2008. Worldwide human relationships inferred from genome-wide patterns of variation. Science 319: 1100-1104.

Luis JR, Rowold DJ, Regueiro M, Caeiro B, Cinnioglu C, Roseman C, Underhill PA, Cavalli-Sforza LL, Herrera RJ. 2004. The Levant versus the Horn of Africa: Evidence for bidirectional corridors of human migrations. Am J Hum Genet 74: 532-544.

Maca-Meyer N, Gonzalez AM, Larruga JM, Flores C, Cabrera VM. 2001. Major genomic mitochondrial lineages delineate early human expansions. BMC Genet 2: 13 .

Macaulay V, Richards M, Hickey E, Vega E, Cruciani F, Guida V, Scozzari R, Batsheva B-T, Sykes B, Torroni A. 1999. The emerging tree of West Eurasian mtDNAs: A synthesis of control region sequences and RFLPs. Am J Hum Genet 64: 232-249.

Malhotra A, Coon H, Feitosa MF, Li WD, North KE, Price RA, Bouchard C, Hunt SC, Wolford JK. 2005. Meta-analysis of genome-wide linkage studies for quantitative lipid traits in African Americans. Hum Mol Genet 14: $3955-$ 3962.

Marth GT, Czabarka E, Murvai J, Sherry ST. 2004. The allele frequency spectrum in genome-wide human variation data reveals signals of differential demographic history in three large world populations. Genetics 166: 351-372.

McDonough CW, Palmer ND, Hicks PJ, Roh BH, An SS, Cooke JN, Hester JM, Wing MR, Bostrom MA, Rudock ME, et al. 2011. A genome-wide association study for diabetic nephropathy genes in African Americans. Kidney Int 79: 563-572.

Mendez Fernando L, Krahn T, Schrack B, Krahn A-M, Veeramah Krishna R, Woerner August E, Fomine Forka Leypey M, Bradman N, Thomas Mark G, Karafet Tatiana M, et al. 2013. An African American paternal lineage adds an extremely ancient root to the human Y chromosome phylogenetic tree. Am J Hum Genet 92: 454-459.

Mishmar D, Ruiz-Pesini E, Golik P, Macaulay V, Clark AG, Hosseini S, Brandon M, Easley K, Chen E, Brown MD, et al. 2003. Natural selection shaped regional mtDNA variation in humans. Proc Natl Acad Sci 100: 171-176. 
Mulcare CA, Weale ME, Jones AL, Connell B, Zeitlyn D, Tarekegn A, Swallow DM, Bradman N, Thomas MG. 2004. The T allele of a single-nucleotide polymorphism $13.9 \mathrm{~kb}$ upstream of the lactase gene (LCT) (C-13.9kbT) does not predict or cause the lactase-persistence phenotype in Africans. Am J Hum Genet 74: 1102-1110.

Newcomer AD, Park HS, O’Brien PC, McGill DB. 1983. Response of patients with irritable bowel syndrome and lactase deficiency using unfermented acidophilus milk. Am J Clin Nutr 38: 257-263.

Newman P. 1980. The classification of Chadic within Afroasiatic. Leiden Universitaire Press, Leiden.

Nielsen R. 2005. Molecular signatures of natural selection. Annu Rev Genet 39: 197-218.

Nurse D. 1997. The contributions of linguistics to the study of history in Africa. Journal Afr Hist 38: 359-391.

Olds LC, Sibley E. 2003. Lactase persistence DNA variant enhances lactase promoter activity in vitro: Functional role as a cis regulatory element. Hum Mol Genet 12: 2333-2340.

Oleksyk TK, Nelson GW, An P, Kopp JB, Winkler CA. 2010. Worldwide distribution of the MYH9 kidney disease susceptibility alleles and haplotypes: Evidence of historical selection in Africa. PLoS ONE 5: el1474.

Ong KL, Cheung BM, Man YB, Lau CP, Lam KS. 2007. Prevalence, awareness, treatment, and control of hypertension among United States adults 1999-2004. Hypertension 49: 69-75.

Pagani L, Kivisild T, Tarekegn A, Ekong R, Plaster C, Gallego Romero I, Ayub Q, Mehdi SQ, Thomas MG, Luiselli D, et al. 2012. Ethiopian genetic diversity reveals linguistic stratification and complex influences on the Ethiopian gene pool. Am J Hum Genet 91: 83-96.

Patterson N, Petersen DC, van der Ross RE, Sudoyo H, Glashoff RH, Marzuki S, Reich D, Hayes VM. 2010. Genetic structure of a unique admixed population: Implications for medical research. Hum Mol Genet 19: 411419.

Pereira L, Macaulay V, Torroni A, Scozzari R, Prata MJ, Amorim A. 2001. Prehistoric and historic traces in the mtDNA of Mozambique: Insights into the Bantu expansions and the slave trade. Ann Hum Genet 65: 439-458.

Phillipson L. 2009. Lithic artefacts as a source of cultural, social and economic information: The evidence from Aksum, Ethiopia. Afr Archaeol Rev 26: 45-58.

Piel FB, Patil AP, Howes RE, Nyangiri OA, Gething PW, Williams TN, Weatherall DJ, Hay SI. 2010. Global distribution of the sickle cell gene and geographical confirmation of the malaria hypothesis. Nat Commun 1: 104.

Plagnol V, Wall JD. 2006. Possible ancestral structure in human populations. PLoS Genet 2: e105.

Poloni ES, Naciri Y, Bucho R, Niba R, Kervaire B, Excoffier L, Langaney A, Sanchez-Mazas A. 2009. Genetic evidence for complexity in ethnic differentiation and history in East Africa. Ann Hum Genet 73: 582-600.

Posnansky M. 1961a. 168. Dimple-based pottery from Uganda. Man 61: 141-142.

Posnansky M. 1961b. Pottery types from archaeological sites in East Africa. J Afr Hist 2: 177-198.

Poulter M, Hollox E, Harvey CB, Mulcare C, Peuhkuri K, Kajander K, Sarner M, Korpela R, Swallow DM. 2003.
The causal element for the lactase persistence/non-persistence polymorphism is located in a $1 \mathrm{Mb}$ region of linkage disequilibrium in Europeans. Ann Hum Genet 67: 298-311.

Poznik GD, Henn BM, Yee M-C, Sliwerska E, Euskirchen GM, Lin AA, Snyder M, Quintana-Murci L, Kidd JM, Underhill PA, et al. 2013. Sequencing Y chromosomes resolves discrepancy in time to common ancestor of males versus females. Science 341: 562-565.

Prugnolle F, Manica A, Balloux F. 2005. Geography predicts neutral genetic diversity of human populations. Curr Biol 15: R159-160.

Quintana-Murci L, Semino O, Bandelt HJ, Passarino G, McElreavey K, Santachiara-Benerecetti AS. 1999. Genetic evidence of an early exit of Homo sapiens sapiens from Africa through eastern Africa. Nat Genet 23: 437-441.

Quintana-Murci L, Quach H, Harmant C, Luca F, Massonnet B, Patin E, Sica L, Mouguiama-Daouda P, Comas D, Tzur S, et al. 2008. Maternal traces of deep common ancestry and asymmetric gene flow between Pygmy hunter-gatherers and Bantu-speaking farmers. Proc Natl Acad Sci 105: 1596-1601.

Quintana-Murci L, Harmant C, Quach H, Balanovsky O, Zaporozhchenko V, Bormans C, van Helden PD, Hoal EG, Behar DM. 2010. Strong maternal Khoisan contribution to the South African coloured population: A case of gender-biased admixture. Am J Hum Genet 86: 611620 .

Ramachandran S, Deshpande O, Roseman CC, Rosenberg NA, Feldman MW, Cavalli-Sforza LL. 2005. Support from the relationship of genetic and geographic distance in human populations for a serial founder effect originating in Africa. Proc Natl Acad Sci 102: 15942-15947.

Rando JC, Pinto F, Gonzalez AM, Hernandez M, Larruga JM, Cabrera VM, Bandelt HJ. 1998. Mitochondrial DNA analysis of northwest African populations reveals genetic exchanges with European, near-eastern, and sub-Saharan populations. Ann Hum Genet 62: 531-550.

Ray N, Currat M, Berthier P, Excoffier L. 2005. Recovering the geographic origin of early modern humans by realistic and spatially explicit simulations. Genome Res 15: 1161-1167.

Reeves-Daniel AM, Iskandar SS, Bowden DW, Bostrom MA, Hicks PJ, Comeau ME, Langefeld CD, Freedman BI 2010. Is collapsing C1q nephropathy another MYH9-associated kidney disease? A case report. Am J Kidney Dis 55: e21-24.

Reich D, Green RE, Kircher M, Krause J, Patterson N, Durand EY, Viola B, Briggs AW, Stenzel U, Johnson PLF, et al 2011. Genetic history of an archaic hominin group from Denisova Cave in Siberia. Nature 468: 1053-1060.

Richards MB, Macaulay VA, Bandelt HJ, Sykes BC. 1998. Phylogeography of mitochondrial DNA in western Europe. Ann Hum Genet 62: 241-260.

Richards M, Macaulay V, Hickey E, Vega E, Sykes B, Guida V, Rengo C, Sellitto D, Cruciani F, Kivisild T, et al. 2000 Tracing European founder lineages in the Near Eastern mtDNA pool. Am J Hum Genet 67: 1251-1276.

Robbins LH. 1972. Archeology in the Turkana District, Kenya. Science 176: 359-366. 
F. Gomez et al.

Rogers AR, Harpending H. 1992. Population growth makes waves in the distribution of pairwise genetic differences. Mol Biol Evol 9: 552-569.

Ronald J, Akey JM. 2005. Genome-wide scans for loci under selection in humans. Hum Genomics 2: 113-125.

Rosenberg NA, Pritchard JK, Weber JL, Cann HM, Kidd KK, Zhivotovsky LA, Feldman MW. 2002. Genetic structure of human populations. Science 298: 2381-2385.

Rosset S, Tzur S, Behar DM, Wasser WG, Skorecki K. 2011. The population genetics of chronic kidney disease: Insights from the MYH9-APOL1 locus. Nat Rev Nephrol 7: 313-326.

Sabeti PC, Reich DE, Higgins JM, Levine HZ, Richter DJ, Schaffner SF, Gabriel SB, Platko JV, Patterson NJ, McDonald GJ, et al. 2002. Detecting recent positive selection in the human genome from haplotype structure. Nature 419: $832-837$.

Sabeti PC, Schaffner SF, Fry B, Lohmueller J, Varilly P, Shamovsky O, Palma A, Mikkelsen TS, Altshuler D, Lander ES. 2006. Positive natural selection in the human lineage. Science 312: 1614-1620.

Salas A, Richards M, De la Fe T, Lareu MV, Sobrino B, Sanchez-Diz P, Macaulay V, Carracedo A. 2002. The making of the African mtDNA landscape. Am J Hum Genet 71: 1082-1111.

Sale MM, Lu L, Spruill IJ, Fernandes JK, Lok KH, Divers J, Langefeld CD, Garvey WT. 2009. Genome-wide linkage scan in Gullah-speaking African American families with type 2 diabetes: The Sea Islands Genetic African American Registry (Project SuGAR). Diabetes 58: 260-267.

Satta Y, Takahata N. 2004. The distribution of the ancestral haplotype in finite stepping-stone models with population expansion. Mol Ecol 13: 877-886.

Saunders MA, Hammer MF, Nachman MW. 2002. Nucleotide variability at G6pd and the signature of malarial selection in humans. Genetics 162: 1849-1861.

Saunier JL, Irwin JA, Strouss KM, Ragab H, Sturk KA, Parsons TJ. 2009. Mitochondrial control region sequences from an Egyptian population sample. Forensic Sci Int Genet 3: e97-103.

Schlebusch CM, Skoglund P, Sjodin P, Gattepaille LM, Hernandez D, Jay F, Li S, De Jongh M, Singleton A, Blum MG, et al. 2012. Genomic variation in seven Khoe-San groups reveals adaptation and complex African history. Science 338: $374-379$.

Scozzari R, Cruciani F, Santolamazza P, Malaspina P, Torroni A, Sellitto D, Arredi B, Destro-Bisol G, De Stefano G, Rickards O, et al. 1999. Combined use of biallelic and microsatellite Y-chromosome polymorphisms to infer affinities among African populations. Am J Hum Genet 65: 829-846.

Segal I, Gagjee PP, Essop AR, Noormohamed AM. 1983. Lactase deficiency in the South African black population. Am J Clin Nutr 38: 901-905.

Seielstad MT, Minch E, Cavalli-Sforza LL. 1998. Genetic evidence for a higher female migration rate in humans. Nat Genet 20: 278-280.

Sikora M, Laayouni H, Calafell F, Comas D, Bertranpetit J. 2010. A genomic analysis identifies a novel component in the genetic structure of sub-Saharan African populations. Eur J Hum Genet 19: 84-88.
Smith AB. 1992. Origins and spread of pastoralism in Africa. Annu Rev Anthropol 21: 125-141.

Smith MW, Patterson N, Lautenberger JA, Truelove AL, McDonald GJ, Waliszewska A, Kessing BD, Malasky MJ, Scafe C, Le E, et al. 2004. A high-density admixture map for disease gene discovery in African Americans. Am J Hum Genet 74: 1001-1013.

Soodyall H, Vigilant L, Hill AV, Stoneking M, Jenkins T. 1996. mtDNA control-region sequence variation suggests multiple independent origins of an "Asian-specific" 9-bp deletion in sub-Saharan Africans. Am J Hum Genet 58: 595-608.

Stefflova K, Dulik MC, Pai AA, Walker AH, Zeigler-Johnson CM, Gueye SM, Schurr TG, Rebbeck TR. 2009. Evaluation of group genetic ancestry of populations from Philadelphia and Dakar in the context of sex-biased admixture in the Americas. PLoS ONE 4: e7842.

Stringer C. 1994. Out of Africa-A personal history. In Origins of anatomically modern humans (ed. Nitecki M, Nitecki D). Plenum, New York.

Stringer CB, Andrews P. 1988. Genetic and fossil evidence for the origin of modern humans. Science 239: 1263 1268.

Sutton J. 1973. The settlement of East Africa. In Zamani (ed. Ogot BA), pp. 70-97. Longmans, Nairobi.

Swallow DM. 2003. Genetics of lactase persistence and lactose intolerance. Annu Rev Genet 37: 197-219.

Templeton A. 2002. Out of Africa again and again. Nature 416: $45-51$.

Thomas MG, Weale ME, Jones AL, Richards M, Smith A, Redhead N, Torroni A, Scozzari R, Gratrix F, Tarekegn A, et al. 2002. Founding mothers of Jewish communities: Geographically separated Jewish groups were independently founded by very few female ancestors. Am J Hum Genet 70: 1411-1420.

Thomason SGaK, T. 1988. Language contact, creolization, and genetic linguistics. University of California Press, Berkeley and Los Angeles.

Tishkoff SA, Goldman A, Calafell F, Speed WC, Deinard AS, Bonne-Tamir B, Kidd JR, Pakstis AJ, Jenkins T, Kidd KK. 1998. A global haplotype analysis of the myotonic dystrophy locus: Implications for the evolution of modern humans and for the origin of myotonic dystrophy mutations. Am J Hum Genet 62: 1389-1402.

Tishkoff SA, Varkonyi R, Cahinhinan N, Abbes S, Argyropoulos G, Destro-Bisol G, Drousiotou A, Dangerfield B, Lefranc G, Loiselet J, et al. 2001. Haplotype diversity and linkage disequilibrium at human G6PD: Recent origin of alleles that confer malarial resistance. Science 293: $455-462$.

Tishkoff SA, Reed FA, Ranciaro A, Voight BF, Babbitt CC, Silverman JS, Powell K, Mortensen HM, Hirbo JB, Osman M, et al. 2007. Convergent adaptation of human lactase persistence in Africa and Europe. Nat Genet 39: $31-40$.

Tishkoff SA, Reed FA, Friedlaender FR, Ehret C, Ranciaro A, Froment A, Hirbo JB, Awomoyi AA, Bodo J-M, Doumbo $\mathrm{O}$, et al. 2009. The genetic structure and history of Africans and African Americans. Science 324: 1035-1044.

Torroni A, Rengo C, Guida V, Cruciani F, Sellitto D, Coppa A, Calderon FL, Simionati B, Valle G, Richards M, et al. 
2001. Do the four clades of the mtDNA haplogroup L2 evolve at different rates? Am J Hum Genet 69: 1348-1356.

Troelsen JT, Olsen J, Moller J, Sjostrom H. 2003. An upstream polymorphism associated with lactase persistence has increased enhancer activity. Gastroenterology 125: 1686-1694.

Tzur S, Rosset S, Shemer R, Yudkovsky G, Selig S, Tarekegn A, Bekele E, Bradman N, Wasser WG, Behar DM, et al. 2010. Missense mutations in the APOL1 gene are highly associated with end stage kidney disease risk previously attributed to the MYH9 gene. Hum Genet 128: 345-350.

United States Renal Data System 2011. USRDS 2011 annual data report: Atlas of chronic kidney disease and end-stage renal disease in the United States. National Institute of Diabetes and Digestive and Kidney Diseases, Bethesda, MD.

Van Beek GW. 1967. Monuments of Axum in the light of South Arabian archeology. J Am Orient Soc 87: 113-122.

Vansina J. 1995. New linguistic evidence and "the Bantu Expansion." J Afr His 36: 173-195.

Veeramah KR, Connell BA, Pour NA, Powell A, Plaster CA, Zeitlyn D, Mendell NR, Weale ME, Bradman N, Thomas MG. 2010. Little genetic differentiation as assessed by uniparental markers in the presence of substantial language variation in peoples of the Cross River region of Nigeria. BMC Evol Biol 10: 92.

Verrelli BC, McDonald JH, Argyropoulos G, Destro-Bisol G, Froment A, Drousiotou A, Lefranc G, Helal AN, Loiselet J, Tishkoff SA. 2002. Evidence for balancing selection from nucleotide sequence analyses of human G6PD. Am J Hum Genet 71: 1112-1128.

Vigilant L. 1990. Control region sequences from African populations and the evolution of human mitochondrial DNA. University of California, Berkeley, CA.

Vigilant L, Stoneking M, Harpending H, Hawkes K, Wilson AC. 1991. African populations and the evolution of human mitochondrial DNA. Science 253: 1503-1507.

Wall JD, Lohmueller KE, Plagnol V. 2009. Detecting ancient admixture and estimating demographic parameters in multiple human populations. Mol Biol Evol 26: 18231827.
Wallace DC, Brown MD, Lott MT. 1999. Mitochondrial DNA variation in human evolution and disease. Gene 238: $211-230$.

Wang S, Lachance J, Tishkoff SA, Hey J, Xing J. 2013. Apparent variation in Neanderthal admixture among African populations is consistent with gene flow from nonAfrican populations. Genome Biol Evol 5: 2075-2081.

Watson E, Bauer K, Aman R, Weiss G, von Haeseler A, Paabo S. 1996. mtDNA sequence diversity in Africa. Am J Hum Genet 59: 437-444.

Watson E, Forster P, Richards M, Bandelt HJ. 1997. Mitochondrial footprints of human expansion in Africa. Am J Hum Genet 61: 691-704.

Weatherall DJ. 2001. Phenotype-genotype relationships in monogenic disease: Lessons from the thalassaemias. Nat Rev Genet 2: 245-255.

Wei W, Ayub Q, Chen Y, McCarthy S, Hou Y, Carbone I, Xue Y, Tyler-Smith C. 2013. A calibrated human Y-chromosomal phylogeny based on resequencing. Genome Res 23: 388-395.

Winkler CA, Nelson GW, Smith MW. 2010. Admixture mapping comes of age. Annu Rev Genomics Hum Genet 11: 65-89.

Wood ET, Stover DA, Ehret C, Destro-Bisol G, Spedini G, McLeod H, Louie L, Bamshad M, Strassmann BI, Soodyall H, et al. 2005. Contrasting patterns of Y chromosome and mtDNA variation in Africa: Evidence for sex-biased demographic processes. Eur J Hum Genet 13: 867-876.

Yang Q, Khoury MJ, Friedman J, Little J, Flanders WD. 2005. How many genes underlie the occurrence of common complex diseases in the population? Int J Epidemiol 34: 1129-1137.

Yotova V, Lefebvre J-F, Moreau C, Gbeha E, Hovhannesyan K, Bourgeois S, Bédarida S, Azevedo L, Amorim A, Sarkisian T, et al. 2011. An X-linked haplotype of Neandertal origin is present among all non-African populations. $\mathrm{Mol}$ Biol Evol 28: 1957-1962.

Zietkiewicz E, Yotova V, Jarnik M, Korab-Laskowska M, Kidd KK, Modiano D, Scozzari R, Stoneking M, Tishkoff S, Batzer M, et al. 1998. Genetic structure of the ancestral population of modern humans. J Mol Evol 47: 146-155. 


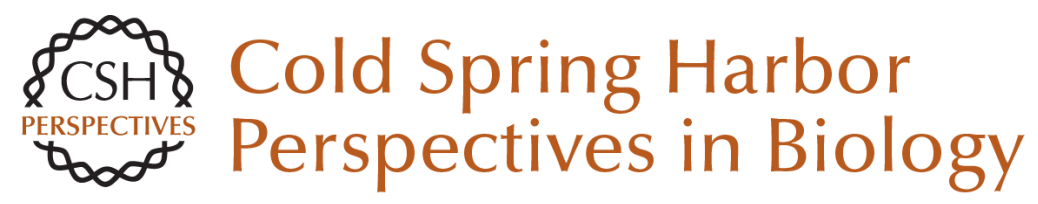

\section{Genetic Variation and Adaptation in Africa: Implications for Human Evolution and Disease}

Felicia Gomez, Jibril Hirbo and Sarah A. Tishkoff

Cold Spring Harb Perspect Biol 2014; doi: 10.1101/cshperspect.a008524

Subject Collection Human Variation

Perspectives on Human Variation through the

Lens of Diversity and Race

Aravinda Chakravarti

A Genomic View of the Peopling and Population Structure of India

Partha P. Majumder and Analabha Basu

Demographic Events and Evolutionary Forces

Shaping European Genetic Diversity

Krishna R. Veeramah and John Novembre

Social Diversity in Humans: Implications and Hidden Consequences for Biological Research Troy Duster
How Genes Have Illuminated the History of Early

Americans and Latino Americans Andrés Ruiz-Linares

Can Genetics Help Us Understand Indian Social History?

Romila Thapar

Genetic Variation and Adaptation in Africa:

Implications for Human Evolution and Disease Felicia Gomez, Jibril Hirbo and Sarah A. Tishkoff

What Type of Person Are You? Old-Fashioned

Thinking Even in Modern Science

Kenneth M. Weiss and Brian W. Lambert

For additional articles in this collection, see http://cshperspectives.cshlp.org/cgi/collection/

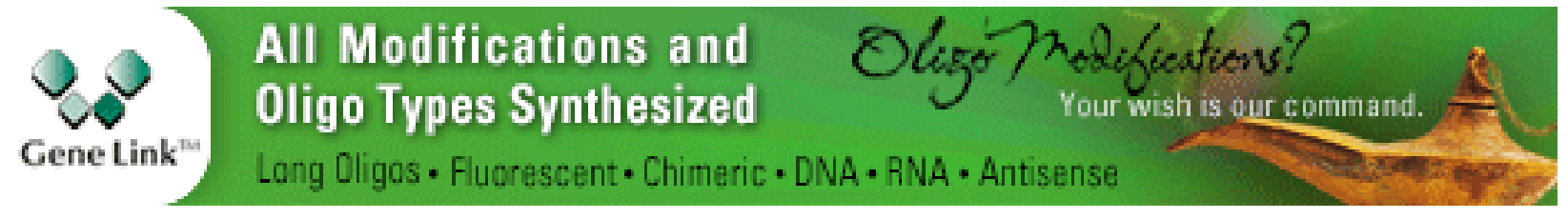

Copyright @ 2014 Cold Spring Harbor Laboratory Press; all rights reserved 